Georgia State University College of Law Reading Room

Faculty Publications By Year

Faculty Publications

$11-2015$

\title{
Gaming the System: The Exemption of Professional Sports Teams From the Fair Labor Standards Act
}

Charlotte S. Alexander

Georgia State University College of Law, calexander@gsu.edu

Nathaniel Grow

University of Georgia, grown@iu.edu

Follow this and additional works at: https://readingroom.law.gsu.edu/faculty_pub

Part of the Benefits and Compensation Commons, Business Law, Public Responsibility, and Ethics Commons, Entertainment, Arts, and Sports Law Commons, Labor and Employment Law Commons, Other Legal Studies Commons, and the Sports Studies Commons

\section{Recommended Citation}

Charlotte S. Alexander \& Nathaniel Grow, Gaming the System: The Exemption of Professional Sports Teams from the Fair Labor Standards Act, 49 U.C. Davis L. Rev. 123 (2015).

This Article is brought to you for free and open access by the Faculty Publications at Reading Room. It has been accepted for inclusion in Faculty Publications By Year by an authorized administrator of Reading Room. For more information, please contact mbutler@gsu.edu. 


\title{
Gaming the System: The Exemption of Professional Sports Teams from the Fair Labor Standards Act
}

\author{
Charlotte S. Alexander ${ }^{+*} \mathcal{E}$ Nathaniel Grow ${ }^{* *}$
}

This article examines a little known exemption to the Fair Labor Standards Act relieving seasonal recreational or amusement employers from their obligation to pay the minimum wage and overtime. After evaluating the existing, confused case law surrounding the exemption, we propose a new, simplified framework for applying the provision. We then apply this framework to a recent wave of FLSA lawsuits brought by cheerleaders, minor league baseball players, and stadium workers against professional sports teams. The article concludes by considering the policy implications of exempting this class of employers from the FLSA's wage and hour requirements.

\section{TABLE OF CONTENTS}

INTRODUCTION

I. THE ORIGINS OF THE FLSA AND SECTION 213(A)(3)

A. The FLSA and Its Exemptions ........................................ 129

B. The Origins and Legislative History of Section 213(a)(3) .. 132

II. STAGES OF A SECTION 213(A)(3) ANALYSIS ............................ 138

A. Identifying the Establishment ......................................... 139

B. Determining the Establishment's Amusement or

Recreational Status

C. Evaluating the Seasonal Nature of the Establishment

† Copyright (C) 2015 Charlotte S. Alexander \& Nathaniel Grow.

* Assistant Professor of Legal Studies, Department of Risk Management and Insurance, J. Mack Robinson College of Business, Georgia State University; secondary appointment, Georgia State University College of Law. The authors are listed in alphabetical order and contributed equally to this work. We thank Pam Brannon for her excellent research assistance.

** Associate Professor of Legal Studies, Terry College of Business, University of Georgia. 
1. Duration of the Establishment's Operations .............. 150

2. Receipt of the Establishment's Revenues .................. 151

III. PROFESSIONAL SPORTS TEAMS AND SECTION 213(A)(3) .......... 153

A. Existing Precedent Applying Section 213(a)(3) to

Professional Sports Teams ............................................ 154

B. The Proper Analysis of Professional Sports Teams Under Section 213(a)(3) .................................................... 158

1. Identifying the Establishment .................................. 158

2. Determining the Establishment's Amusement or Recreational Status .................................................. 161

3. Evaluating the Seasonal Nature of the

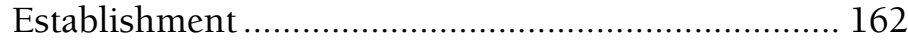

C. Implications for Pending FLSA Cases Against

Professional Sports Teams ............................................... 166

IV. IMPLICATIONS FOR PUBLIC POLICY AND PROPOSALS FOR

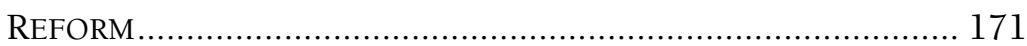

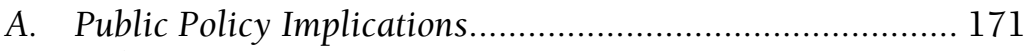

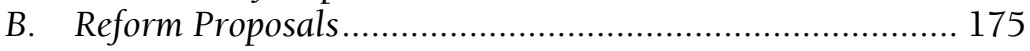

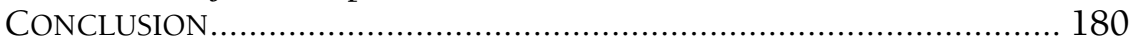




\section{INTRODUCTION}

Alexa Brenneman began working as a cheerleader for the National Football League's ("NFL") Cincinnati Bengals in 2013.1 As a "BenGal," she spent more than 300 hours performing at home games, attending mandatory practices, posing for and promoting the official Ben-Gals calendar, and appearing at required charity events. ${ }^{2}$ For these efforts, she was paid a total of $\$ 855$, or approximately $\$ 2.85$ per hour. ${ }^{3}$ Ms. Brenneman filed suit against the Bengals in 2014, alleging that the team - valued at nearly $\$ 1$ billion ${ }^{4}$ - failed to pay her the $\$ 7.25$ hourly minimum wage guaranteed by the federal Fair Labor Standards Act ("FLSA"). 5

Ms. Brenneman is not alone: cheerleaders for the NFL's Oakland Raiders, ${ }^{6}$ Tampa Bay Buccaneers, ${ }^{7}$ New York Jets ${ }^{8}$ and Buffalo Bills ${ }^{9}$

1 Class Action Complaint at 2, Brenneman v. Cincinnati Bengals, Inc., No. 1:14cv-136 (S.D. Ohio Feb. 11, 2014) [hereinafter Brenneman Complaint].

2 Id. at 2, 6-7.

3 Id. at 2.

4 NFL Team Valuations, Cincinnati Bengals, FORBES, http://www.forbes.com/teams/ cincinnati-bengals/ (last visited July 7, 2015) (listing team valuation as of August 2014 as $\$ 990$ million).

5 Brenneman Complaint, supra note 1, at 13-14; see also Fair Labor Standards Act, 29 U.S.C. \& 206 (2012) (setting the hourly federal minimum wage at \$7.25).

6 See, e.g., Class Action Complaint, Sanchez v. Nat'l Football League, No. RG15756086 (Cal. Super. Ct. Jan. 26, 2015) [hereinafter Sanchez Complaint] (asserting wage and hour claims under California state law); Class Action Complaint, Lacy T. v. Oakland Raiders, No. RG14710815 (Cal. Super. Ct. Sept. 4, 2014) (same); Class Action Complaint, Caitlin Y. v. Nat'l Football League, No. RG14727746 (Cal. Super. Ct. June 4, 2014) [hereinafter Caitlin Y. Complaint] (same).

7 See, e.g., Collective Action Complaint, Pierre-Val v. Buccaneers Ltd. P'ship, No. 8:14-cv-1182-T-33EAJ (M.D. Fla. May 19, 2014) (asserting FLSA claims).

8 See, e.g., Class Action Complaint, Krystal C. v. New York Jets LLC, No. L004282-14 (N.J. Super. Ct. May 6, 2014) [hereinafter Krystal C. Complaint] (asserting wage and hour claims under New Jersey state law).

9 See Complaint, Jaclyn S. v. Buffalo Bills, Inc., No. 804088/2014 (N.Y. Sup. Ct. Apr. 22, 2014) [hereinafter Jaclyn S. Complaint] (asserting wage and hour claims under New York state law). Two days after Jaclyn S. filed her lawsuit, the Buffalo Bills cheerleading squad suspended its operations indefinitely. See Buffalo Bills Cheerleaders Pack Up Pom-Poms After Lawsuit, CBS News (Apr. 25, 2014), http://www.cbsnews. com/news/buffalo-bills-cheerleaders-pack-up-pom-poms-after-lawsuit/.

Of the seven cheerleader lawsuits filed to date, Lacy T. and Pierre-Val have settled. Joint Motion for Preliminary Approval of Class Settlement Filed for Plaintiff, Lacy T. v. Oakland Raiders, No. RG14710815 (Cal. Super. Ct. Sept. 4, 2014); Notice of Settlement, Pierre-Val v. Buccaneers Ltd. P'ship, No. 8:14-cv-1182-T-33EAJ (M.D. Fla. Dec. 24, 2014) (No. 41). At least two cheerleaders have opted out of the settlement in the Lacy $T$. case, however, and are continuing to pursue their claims on an individual basis. See Lisa Fernandez, "I'm Not in the Front Anymore": Raiderette Opts out of Class 
have also filed suit against their teams alleging that their pay fell below the floor set by the FLSA and/or state wage and hour laws. ${ }^{10}$ Similar lawsuits were filed under the FLSA in 2014 and 2015 by former minor league baseball players - who sued Major League Baseball ("MLB") and its thirty teams ${ }^{11}$ - as well as MLB baseball scouts 12 and interns employed by the National Basketball Association's ("NBA") Los Angeles Clippers. ${ }^{13}$ These cases follow previous minimum wage and

Action Wage Labor Settlement with Raiders, NBCBAyAREA.COM (Nov. 17, 2014), http://www.nbcbayarea.com/news/local/Raiderette-Opts-Out-of-Class-Action-WageLabor-Settlement-With-Raiders-282936121.html. The remaining cheerleader lawsuits are still pending at the time of this writing.

10 A segment on the cheerleader lawsuits on HBO's Real Sports with Bryant Gumbel reported that some cheerleaders' effective wages are as low as $\$ 0.05$ per hour when all of their duties are accounted for. Real Sports with Bryant Gumbel: Bring It On (HBO television broadcast June 24, 2014). Some cheerleader lawsuits also allege that the plaintiffs were subjected to an array of harassing, degrading, and sexist treatment. For example, one of the suits against the Oakland Raiders alleges that the plaintiffs were required to change into their uniforms in "crowded public restrooms with little to no privacy" and to appear at fan events that "involved inappropriate and/or degrading comments and groping from often-inebriated attendees." Caitlin Y. Complaint, supra note 6, at 6-7. The lawsuit against the Buffalo Bills alleges that cheerleaders were required to participate in a "Calendar Release Party" while wearing only a bikini bathing suit, "with no stage or security provided," where they were "groped and touched inappropriately by audience members during the performance." Jaclyn S. Complaint, supra note 9, at 12-13. The Bills lawsuit further details the team's onerous and intrusive requirements for cheerleader hygiene, including "how to properly wash 'intimate areas,' and how often to change tampons." Id. at 18. An attorney for one set of Oakland Raiders plaintiffs has also noted that the team's mascot, presumed to be a man, earns $\$ 40,000$ per year, plus benefits. See Robin Abcarian, Cheerleaders Add New Defendant to Wage Theft Lawsuits: The NFL, L.A. TIMES (June 6, 2014), http://www.latimes.com/local/abcarian/la-me-ra-second-raiderette-lawsuit-20140606column.html. The issues of sex discrimination and exploitation raised by these cases is beyond the scope of this article's focus on FLSA exemptions, but is nevertheless an essential element of the "story" behind cheerleaders' extremely low pay.

11 See Complaint at 1, Marti v. Office of the Comm'r of Baseball, No. 3:14-cv03289-KAW (N.D. Cal. July 21, 2014) (asserting claims under the FLSA and state wage and hour law); Complaint at 3, Senne v. Office of the Comm'r of Baseball, No. 3:14-cv-00608-JCS (N.D. Cal. Feb. 7, 2014) (same). These two suits have been consolidated, and the judge recently dismissed eight teams from the suit for lack of jurisdiction. See Order Re: Motions to Dismiss and Motions to Transfer at 47, Senne, v. Kansas City Royals Baseball Corp., No. 14-cv-00608-JCS (2015).

12 See Complaint at 2, Wyckoff v. Office of the Comm'r of Baseball, No. 1:15-cv05186 (S.D.N.Y. July 2, 2015) (claiming failure to pay overtime in violation of the FLSA).

13 See Complaint, Cooper v. LAC Basketball Club, Inc., No. 2:14-cv-04445 (C.D. Cal. June 10, 2014) (pursuing relief on behalf of a class of former unpaid interns for the Los Angeles Clippers). This suit has been voluntarily dismissed without prejudice by the plaintiff. Notice of Voluntary Dismissal, Cooper v. LAC Basketball Club, Inc., 
overtime lawsuits brought against professional sports teams by clubhouse attendants, ${ }^{14}$ stadium groundskeepers, ${ }^{15}$ and ticket sales and fan relations personnel. ${ }^{16}$

At first glance, suits like Ms. Brenneman's would appear to be a "slam dunk" (or touchdown, as the case may be) for the plaintiffs: an hourly wage of $\$ 2.85$ is by all measures far below the $\$ 7.25$ minimum, and a professional sports franchise worth over one billion dollars would likely be a particularly unsympathetic defendant in this context. However, the success of minimum wage and overtime lawsuits against professional sports teams is hardly guaranteed due to a relatively obscure exemption to the FLSA, 29 U.S.C. \& 213(a)(3), which relieves seasonal "amusement or recreational" establishments from minimum wage and overtime obligations.

Courts that have considered this exemption to date have adopted differing approaches when applying Section 213(a)(3) to professional sports franchises because while sports teams clearly provide "amusement" services to the public, their operations may or may not qualify as "seasonal," depending on whether one focuses only on the length of their playing season or the increasingly year-round nature of their business as a whole. ${ }^{17}$ This lack of uniformity has created uncertainty regarding the extent to which the FLSA covers amusement and recreation workers not only in the professional sports industry, but in other fields as well. ${ }^{18}$

No. 2:14-cv-04445 (C.D. Cal. June 18, 2014) (No. 12)

14 See Adams v. Detroit Tigers, Inc., 961 F. Supp. 176, 179 (E.D. Mich. 1997) (lawsuit by "batboys" who worked in team clubhouse).

15 See Jeffery v. Sarasota White Sox, Inc., 64 F.3d 590, 592-93 (11th Cir. 1995) (lawsuit by stadium groundskeeper).

16 See Chen v. Major League Baseball, 6 F. Supp. 3d 449, 451 (S.D.N.Y. 2014) (lawsuit by fan relations volunteer); Liger v. New Orleans Hornets NBA Ltd. P'ship, 565 F. Supp. 2d 680, 686 (E.D. La. 2008) (lawsuit by sales and fan relations workers).

17 Compare Jeffery, 64 F.3d at 596 (focusing on playing-season length), with Bridewell v. Cincinnati Reds, 68 F.3d 136, 139 (6th Cir. 1995) (focusing on yearround operations)

18 For example, three FLSA lawsuits were filed in 2013 by immigrant workers with temporary visas employed by traveling carnivals and fairs, who asserted that they worked under extremely exploitative conditions and did not receive the minimum wage or overtime. See, e.g., Am. Univ. Wash. Coll. of Law Immigrant Justice Clinic \& Centro de los Derechos del Migrante, Inc., Taken for a Ride: Migrant Workers in the U.S. Fair and Carnival Industry, at vi (Feb. 2013), http://www.cdmigrante.org/wp-content/uploads/ 2013/02/110145_Taken_for_a_Ride_Report_Final.pdf (describing state fair worker Samuel Rosales Rios who worked at a Greek food stand between sixteen and seventeen hours per day, sometimes at a wage of $\$ 1.00$ per hour). The defendants in all three lawsuits defended themselves on the basis of \& 213(a)(3). Amended Answer to Complaint at 17, Doe I v. Butler Amusements, Inc., No. 3:13-cv-03027 (N.D. Cal. Aug. 
Moreover, the fact that professional sports franchises - teams that are in many cases worth hundreds of millions or even billions of dollars ${ }^{19}$ - may be exempt from the FLSA raises questions about the exemption's policy rationale. Because the exemption includes no revenue threshold, employers that can easily afford to comply with the law are nevertheless able to evade the basic wage and hour protections afforded to most workers. In addition, the fact that employees of professional sports teams may in some cases legally be paid subminimum wages casts doubt on the true economic benefits these franchises impart to their host communities, undercutting the job creation and economic development justifications that teams frequently offer when seeking subsidies from taxpayers (often in the form of new, publicly financed stadiums or arenas). ${ }^{20}$

While other FLSA exemptions have been the subject of much popular and academic attention, ${ }^{21}$ this seasonal amusement or

22, 2014) (No. 70); Answer to Amended Complaint at 19, Garcia v. E.J. Amusements of N.H., Inc., No. 1:13-cv-12536 (D. Mass. Nov. 24, 2014); Amended Answer and Affirmative Defenses to Complaint at 2, Morales-Toledano v. Deggeller Attractions, Inc., No. 2:13-cv-14106-JEM (S.D. Fla. Jan. 17, 2014) (No. 62). The plaintiffs in Doe survived summary judgment on the question of the exemption's application and the parties were in settlement talks as of December 2014. Doe v. Butler Amusements, Inc., 71 F. Supp. 3d 1125 (N.D. Cal. 2014). The Morales-Toledano plaintiffs dismissed their FLSA claims in January 2014, acknowledging the applicability of the exemption. Final Order of Dismissal With Prejudice, Morales-Toledano, No. 2:13-cv-14106-JEM (S.D. Fla. Jan. 17, 2014) (No. 77). The Garcia case is in discovery as of January 2015.

19 See, e.g., NFL Team Valuations, Dallas Cowboys, FORBES, http://www.forbes.com/ teams/dallas-cowboys/ (last visited July 14, 2015) (listing team valuation as of August 2014 as $\$ 3.2$ billion).

20 See, e.g., New Vikings Stadium Economic Impact, MinnesotaVikings.COM, http://www.vikings.com/stadium/new-stadium/economic-impact.html (last visited July 14, 2015) ("Not only will a Vikings stadium keep one of Minnesota's biggest assets in the State, but building a new facility will also support thousands of jobs and generate significant economic activity at a time when the State desperately needs it. . . Upon completion of the stadium, 3,400 full and part-time jobs will be supported by the economic activity generated by a new stadium.").

21 See, e.g., Marc Linder, Farm Workers and the Fair Labor Standards Act: Racial Discrimination in the New Deal, 65 TEX. L. REV. 1335, 1353-54 (1987) (describing the racist origins of the farmworker and domestic worker exemptions to the FLSA); Deborah C. Malamud, Engineering the Middle Classes: Class Line-Drawing in New Deal Hours Legislation, 96 MiCH. L. REV. 2212, 2220 (1998) (describing the "FLSA's socalled "white-collar exemptions" as "the subject of controversy"); Regan C. Rowan, Comment, Solving the Bluish Collar Problem: An Analysis of the DOL's Modernization of the Exemptions to the Fair Labor Standards Act, 7 U. PA. J. LAB. \& EMP. L. 119, 119 (2004) (discussing FLSA overtime exemptions and citing the Wall Street Journal as commenting, "[w]ho should be eligible for overtime is a hot economic and political issue"). 
recreation exemption has, to date, largely been ignored. ${ }^{22}$ This article therefore seeks to advance the existing academic literature on the FLSA and its exemptions by providing the first detailed consideration of Section 213(a)(3). The article begins in Part I by providing a brief primer on the FLSA and its exemptions, before tracing the origins and legislative history of Section 213(a)(3). Part II surveys the confused case law applying Section 213(a)(3) and proposes a simple new framework for analyzing defendants' entitlement to the exemption. Using this framework, Part III then explores the status of professional sports teams under the exemption, ultimately concluding that when analyzed correctly, teams will often qualify for the Section 213(a)(3) exemption in at least some areas of their operations. Part IV concludes by examining the policy implications of this analysis, not only for the professional sports industry, but also for the FLSA's exemptions generally.

\section{The ORIGINS Of THE FLSA AND SECTION 213(A)(3)}

\section{A. The FLSA and Its Exemptions}

The FLSA was enacted in 1938 as a key component of President Franklin D. Roosevelt's New Deal legislative agenda. ${ }^{23}$ As described by the President, the legislation's twin requirements of a minimum hourly

22 Three law review articles have mentioned the exemption in annual surveys of circuit court opinions. Christina A. Lorino et al., Eleventh Circuit: Survey of Recent Decisions, 39 Cumb. L. REV. 819, 865-67 (2009) (summarizing a 2008 Eleventh Circuit decision in which defendant raised § 213(a)(3) defense); Stephen W. Mooney \& Leigh Lawson Reeves, Labor Law, 47 MERCER L. Rev. 891, 896-97 (1996) (surveying the 1995 labor law decisions by the Eleventh Circuit and summarizing the Jeffery $v$. Sarasota White Sox case discussed infra notes 144-46); E. Fredrick Preis, Jr., Labor Law, 36 LOY. L. REV. 885, 897-98 (1990) (summarizing a 1989 Fifth Circuit decision in which defendant raised \& 213(a)(3) defense). Meanwhile, other articles that contain substantive analyses of workers' FLSA rights mention the existence of the exemption in passing. See, e.g., Leda E. Dunn, Note, "Protection" of Volunteers Under the Federal Employment Law: Discouraging Voluntarism?, 61 ForDHAM L. REV. 451, 472 n.46 (1992) (listing \& 213(a)(3) as an example of FLSA exemptions). Finally, one recent law review article focused on Section 213(a)(3) in the context of the circuit split currently existing between the Sixth and Eleventh Circuits, discussed in depth infra notes 144-55 and accompanying text. See Adam Epstein, Attack of the Cheerleaders! Allegations of Violations of the FLSA on an Uncertain Landscape, 21 J.L. BUS. \& ETH. 23, 30-31 (2015).

23 See Deborah Thompson Eisenberg, Regulation by Amicus: The Department of Labor's Policy Making in the Courts, 65 FLA. L. ReV. 1223, 1232 (2013) ("President Franklin Roosevelt pushed for the FLSA, a centerpiece of the New Deal, to end starvation wages and intolerable hours."'). 
wage and premium overtime pay were intended to provide workers with "a fair day's pay for a fair day's work." 24 According to President Roosevelt, "A self-supporting and self-respecting democracy can plead... no economic reason for chiseling workers' wages or stretching workers' hours." 25 Yet, despite its noble aims, the FLSA contains a variety of exemptions that allow employers to deprive workers of the statute's basic economic protections. Perhaps the most well-known of these provisions is the so-called "white collar" exemption, which denies overtime pay to "any employee employed in a bona fide executive, administrative, or professional capacity." 26 Many domestic and farm workers likewise may not claim the minimum wage or overtime pay under the FLSA, ${ }^{27}$ and tipped workers such as restaurant wait staff receive a special, sub-minimum wage. ${ }^{28}$ These exemptions lend a "Swiss cheese" character to the statute: at one time or another, seventeen separate occupations or industries have been exempt from both the minimum wage and overtime requirements, ${ }^{29}$ while another thirty have been exempt from the obligation to pay overtime. ${ }^{30}$

Many of the FLSA's exemptions have received significant scholarly and public attention, both for their seemingly haphazard nature and the sometimes troubling history explaining why particular groups of workers have been denied the statute's protection. For example, as Professor Marc Linder pointed out in his exhaustive history of the farm and domestic worker exemptions, those occupations traditionally held by African Americans - were carved out of FLSA coverage at the behest of white Southern Congressmen in exchange for their votes for the bill. ${ }^{31}$ Other exemptions are so specific as to suggest

24 A.H. Phillips, Inc. v. Walling, 324 U.S. 490, 493 (1945) (citing Message of the President to Congress, May 24, 1934).

25 Jonathan Grossman, Fair Labor Standards Act of 1938: Maximum Struggle for a Minimum Wage, U.S. DEP'T OF LABOR (1978), available at http://www.dol.gov/dol/ aboutdol/history/flsa1938.htm.

2629 U.S.C. \& 213(a)(1) (2012).

2729 U.S.C. \& 213(a)(6) (exempting some farmworkers from minimum wage and overtime protections); 29 U.S.C. \& 213(a)(15) (exempting casual babysitters and domestic companionship workers from minimum wage and overtime protections).

2829 U.S.C. § 203(m) (2012) (setting out minimum wage requirements for tipped workers); U.S. Dep't of Labor, Wage \& Hour Div., Fact SheEt \#15: Tipped EMPloyees UNDER THE FAIR LABOR STANDARDS ACT (FLSA) (2013), available at http:// www.dol.gov/whd/regs/compliance/whdfs15.pdf (setting tipped workers' required cash wage at $\$ 2.13$ per hour).

2929 U.S.C. \& $213(\mathrm{a})$.

3029 U.S.C. \& 213(b).

31 Linder, supra note 21, at 1353-54 ("By the time the FLSA was drafted, the 
similar trades of votes for special interest concessions. ${ }^{32}$ The FLSA exempts, for example, workers who catch, harvest, or process "fish, shellfish, crustacea, sponges, seaweeds, or other aquatic forms of animal and vegetable life;" 33 "homeworker[s] engaged in the making of wreaths composed principally of natural holly, pine, cedar, or other evergreens;"34 and "switchboard operator[s] employed by an independently owned public telephone company which has not more than seven hundred and fifty stations." 35 As the Fifth Circuit Court of Appeals has commented:

If there is any unifying principle underlying the exemptions in the FLSA, it is not evident in the Act's words or its legislative history. Reading the Act's legislative history and its exemptions leads one to conclude that the exemptions were created simply to ensure the Act's passage. ${ }^{36}$

Thus, there may not be, as President Roosevelt claimed, an "economic reason for chiseling workers' wages or stretching workers' hours," 37 but there appears to be a political one, as numerous occupations and industries have been exempted from the statute in exchange for the support of special interest groups. Not only does this hodgepodge of exemptions deprive many of our nation's most vulnerable workers of basic economic protections, but the exemptions also present both administrative $e^{38}$ and statutory interpretation

exclusion of farm workers from New Deal economic legislation had become such a fixed component of New Deal politics that the drafters no longer considered the issue. Consequently, understanding the purpose of the exclusion requires an examination of earlier New Deal legislation and the treatment accorded racial minorities by these programs. Only by analyzing the pervasive exclusions of minorities from the New Deal, especially the treatment accorded minority farm workers, is it possible to grasp the effect of racial discrimination on congressional consideration of the FLSA.").

32 Glenn R. Moore, The Scope of Coverage Under the Fair Labor Standards Act of 1938, 30 WASH. \& LEE L. REV. 149, 156 (1973) ("[S] ome industries which might have been compelled to comply with the terms of the Act appear to have been successful in lobbying so as to receive favorable treatment from its terms.").

3329 U.S.C. \& 213(a)(5).

3429 U.S.C. $\$ 213(\mathrm{~d})$.

3529 U.S.C. \& 213(a)(10).

36 Brennan v. Texas City Dike \& Marina, Inc., 492 F.2d 1115, 1117 (5th Cir. 1974).

37 Grossman, supra note 25.

38 See, e.g., The Fair Labor Standards Act: Is It Meeting the Needs of the Twenty-First Century Workplace?: Hearing Before the Subcomm. on Workforce Protections, Comm. on Educ. and the Workforce, 112th Cong. 26 (2011) (calling on Congress to amend the FLSA's "complex, difficult to interpret, and hard to apply" white collar exemption); Yoram Margalioth, The Case Against Tipping, 9 U. PA. J. LAB. \& EMP. L. 117, 142 (2006) (noting that the FLSA's treatment of tipped employees "is quite confusing and 
challenges, ${ }^{39}$ as employers struggle to determine which of their employees is and is not entitled to minimum wage and overtime protection.

B. The Origins and Legislative History of Section 213(a)(3)

Section 213(a)(3) exempts from the FLSA's minimum wage and overtime protections:

[A]ny employee employed by an establishment which is an amusement or recreational establishment ... if (A) it does not operate for more than seven months in any calendar year, or (B) during the preceding calendar year, its average receipts for any six months of such year were not more than $331 / 3$ per centum of its average receipts for the other six months of such year.... ${ }^{40}$

Unlike other FLSA exemptions, this provision has received little popular or academic attention, though its impact on excluded workers is no less significant. ${ }^{41}$ And like many other FLSA exemptions, Section 213(a)(3)'s presence in the statute seems to be largely driven by political expediency; its effect is to define some workers' labor as being less valuable than others' without any clear policy or economic rationale.

The exemption's origins date back to 1961, when a set of amendments was passed extending the minimum wage and overtime for the first time to retail and service workers, who previously had no such rights. ${ }^{42}$ However, this expansion was limited by an exemption for all retail or service employers with annual revenues below $\$ 1$ million, as well as employees of any "amusement or recreational establishment that operates on a seasonal basis" without regard to revenue. ${ }^{43}$

does not seem to promote any clear policy goal").

39 Texas City Dike, 492 F.2d at 1117 ("The absence of a unifying principle makes the exemptions' interpretation a difficult task.").

4029 U.S.C. \& $213(\mathrm{a})(3)$.

41 See supra note 22.

42 See Brock v. Louvers \& Dampers, Inc., 817 F.2d 1255, 1256 (6th Cir. 1987) ("The original version of the exemption at issue here was enacted in the Fair Labor Standards Amendments of 1961."); Gerald Mayer, Benjamin Collins \& David H. Bradley, Cong. Research Serv., The Fair Labor Standards Act (FLSA): An Overview 18 (2013).

43 Fair Labor Standards Act Amendments of 1961, Pub. L. No. 87-30 at 66 (1961) (amending 29 U.S.C. $\$ 203(\mathrm{~s})(1)$ to extend FLSA coverage to retail and service 
The amusement or recreational provision became its own standalone exemption a few years later, in 1966, as part of another set of amendments. ${ }^{44}$ This new version, which still applies today, continued to cover all amusement or recreational establishments without regard to revenue, and now defined seasonality with reference to either the length of the establishment's operations (seven months or less in any calendar year) or fluctuations in receipts between high and low periods (the low period's average receipts must be one-third or less of the high period's average receipts). ${ }^{45}$

Courts have characterized the exemption's legislative history as "skimpy" and "sparse." 46 However, statements in the relevant House and Senate Reports and debate in both houses of Congress provide some guidance regarding not only the types of employers that Congress envisioned falling within the exemption, but also Congress' conception of seasonality.

Scattered throughout the legislative history are various lists of employer types offered as illustrations of the exemption's coverage. A 1961 report by the Senate Committee on Labor and Public Welfare, for example, describes establishments exempt under the provision as "typically those operated by concessionaires at amusement parks and

employers with annual revenues over $\$ 1$ million); id. at 71 (amending 29 U.S.C. \& 213(a)(2)(i)-(ii) to exempt retail and service employers not covered by § 203(s)(1) and, separately, seasonal amusement or recreational enterprises regardless of annual revenue); see also H.R. REP. NO. 87-75, at 98 (1961) (describing Senate version of 1961 amendments as exempting from the FLSA "amusement and recreational establishments operating on a seasonal basis"); MAYER, COLLINS \& BRADLEY, supra note 42 , at 18 (describing the 1961 FLSA amendments as requiring "employers of retail workers in enterprises with annual sales in excess of $\$ 1$ million ... to pay minimum wage and overtime rates").

44 Fair Labor Standards Act Amendments of 1966, Pub. L. No. 89-601 at 833 (1966) (amending the FLSA to insert the current language of the exemption); Brock v. Louvers \& Dampers, Inc., No. C-1-84-1291, 1985 WL 6452, at *13-14 (S.D. Ohio Sept. 17, 1985) (describing the legislative history of 29 U.S.C. § 213(a)(3)).

4529 U.S.C. \& 213(a)(3); Marshall v. New Hampshire Jockey Club, Inc., 562 F.2d 1323, 1329 (1st Cir. 1977) ("The current wording seems to have been intended to establish criteria for seasonality, and by eliminating the 'retail and service' language to make plain that employees of seasonal amusement or recreational companies generally are exempt.").

46 See, e.g., Brennan v. Texas City Dike \& Marina, Inc., 492 F.2d 1115, 1118 (5th Cir. 1974) ("Although it is skimpy, [the legislative history] suggests that the exemption does not cover establishments whose sole or primary activity is selling goods."); Chen v. Major League Baseball, 6 F. Supp. 3d 449, 455 (S.D.N.Y. 2014) (describing the exemption's legislative history as "sparse"); see also Brock, $1985 \mathrm{WL}$ 6452 , at *13 ("The purpose of the amusement and recreational exemption is neither explained in the legislative history of the 1961 amendments nor the legislative history of the 1966 amendments."). 
beaches and [that] are in operation for 6 months or less a year." 47 This statement is replicated in the U.S. Department of Labor regulation implementing the exemption: "Typical examples of such are the concessionaires at amusement parks and beaches." 48 In addition, during the 1961 debates, a House member asked for and received confirmation that the exemption would apply to "dude ranches, seasonal operations... which operate for only 3 to 6 months of the year[.]" 49

In 1965, there was an unsuccessful effort in the House to eliminate the minimum wage portion of the exemption while retaining the overtime waiver. ${ }^{50}$ At the time, a report by the House Committee on Education and Labor characterized the exemption as applying to "such seasonal recreational or amusement activities as amusement parks, carnivals, circuses, sports events, parimutuel racing, sport boating or fishing, and other similar or related activities ...."51

The following year, senators engaged in a relatively lengthy debate over the exemption's scope during their deliberation of the 1966 FLSA amendments, which ultimately resulted in the passage of the exemption's current version. The sticking point in the debate was the status of resort or recreational hotels. Senator A. Willis Robertson of Virginia sought to add language that would exempt "any hotel patronized by a majority of its guests primarily for recreational purposes." 52 He also sought to "give [employers] a little more favorable break" in the receipts test for seasonality. ${ }^{53}$ Instead of comparing average receipts between two six-month periods, Senator Robertson proposed comparing actual receipts for any five months with actual receipts for the other seven months. ${ }^{54}$

Though Senator Robertson acknowledged that the exemption was originally "framed with reference to the recreational concessions in the national parks," 55 he and his allies argued that the expansion would

47 S. ReP. No. 87-145, at 193 (1961).

4829 C.F.R. \& 779.385 (2011).

49107 CONG. REC. 4,792 (Mar. 24, 1961) (statement of Rep. Rogers).

50 H.R. REP. NO. 89-871, at 26-27 (1965).

51 Id. at 51. During the later debates over the 1966 amendments, a House member described the seasonal amusement or recreational exemption using nearly identical language. 112 CONG. REC. 11,293 (May 24, 1966) (statement of Rep. O'Neill) (defining "amusement or recreational establishments" as "amusement parks, sports events, parimutuel racing, sport boating or fishing, and similar activities . . ..").

52112 CONG. REC. 20,596 (Aug. 25, 1966) (statement of Sen. Robertson).

53 Id. at $20,593$.

54 Id.

55 Id. 
allow resort hotels to stave off "competition with hotels in Bermuda and offshore islands." 56 If U.S. resorts were subject to the FLSA, Senator Robertson feared that Congress "would be legislating unemployment." 57 Echoing white Southern advocacy for the farm and domestic worker exemptions almost thirty years before, Senator Robertson expounded on the job-destruction point in explicitly racial terms. He described the "fine group of colored waiters" who worked in the dining room at The Homestead, a luxury Virginia resort hotel.58 According to Senator Robertson, these men "sing spirituals on Sunday mornings and wait on tables. They do not come in to look at empty chairs. [Failing to exempt hotels like the Homestead from the FLSA] will legislate them out of a job," with the result that "those boys would not be in the dining room." 59 Although cast in ostensibly more benevolent terms, the end result of Senator Robertson's position was the same as that pursued by his white Southern lawmaker predecessors: the exclusion of a set of African-American employees from the basic wage and hour protections of the FLSA.

Senator Ralph Yarborough of Texas countered Senator Robertson during the debates, characterizing the exemption as covering only amusement parks "which [are] open in the summer or in the winter. $\mathrm{T}$ [his] section has no application to hotels...."60 According to Senator Yarborough, the exemption should properly apply only to truly seasonal operations. He noted that "census data indicate a trend for resort hotels to operate for longer periods of time each year. That is because in hot areas air conditioning has been developed. Also, some southern hotels are now manufacturing artificial snow for skiing and are installing ski lifts." 61 Even Senator Robertson acknowledged that resort hotels "have to operate all the year around, because if they do not keep their trained workers employed, they could not open up again when the busy season comes." 62 In the end, Senator Yarborough's position carried the day, as the version of the exemption that was ultimately enacted in 1966, and is still in effect today, included none of Senator Robertson's proposed language.

56 Id. (statement of Sen. Fannin).

57 Id. (statement of Sen. Robertson).

58 Id. at 20,594 (statement of Sen. Robertson).

59 Id.

60 Id. (statement of Sen. Yarborough); see also id. at 20,791 (Aug. 26, 1966) ("We have an exemption in the bill for amusement parks. But this amendment would expand that language ....").

61112 CONG. REC. 20,792 (Aug. 26, 1966) (statement of Sen. Yarborough).

62 Id. at 20,593 (Aug. 25, 1966) (statement of Sen. Robertson). 
Thus, the legislative history, though relatively thin, suggests three things about Section 213(a)(3). First, the archetypal seasonal amusement or recreational establishment was seasonal in the climatological sense of the word, in that it was highly weatherdependent. Each example of a covered enterprise in the legislative history tended to operate in the 1960s only in the warm months: amusement parks, beaches, dude ranches, national park concessions, carnivals, circuses, sports events, parimutuel racing, and sport boating or fishing. ${ }^{63}$ During the 1966 debates, Senator Yarborough even commented on the new phenomena of resort hotels' using air conditioning and constructing artificial ski areas to defy the weather; his resistance to extending the exemption to these establishments suggests that such hotels were more resilient and stable, and less deserving of an exemption, than their truly seasonal counterparts. The exemption therefore seems crafted to provide protection to a class of businesses that would find payment of the minimum wage and overtime difficult due to the instability and economic vulnerability introduced by their short, weather-dependent operating seasons. ${ }^{64}$

Second, the legislative history's focus on summertime amusement or recreational operations suggests another potential motivation for the exemption's passage. As the Tenth Circuit has speculated, the exemption may have been designed "to allow recreational facilities to employ young people on a seasonal basis and not have to pay the relatively high minimum wages required by the Fair Labor Standards Act." 65 Although the exemption's legislative history does not mention a specific intent to target young workers (a relatively powerless, economically vulnerable group), ${ }^{66}$ statements during the Senate debate

63 See id.

64 The Sixth Circuit has adopted a similar view of the intended coverage of the exemption: "The logical purpose of the provision is to exempt the type of amusement and recreational enterprises ... which by their nature, have very sharp peak and slack seasons. These businesses argue that they should not be held to the same wage and hour requirements as permanent, year-round operations. Their particular character may require longer hours in a shorter season, their economic status may make higher wages impractical, or they may offer non-monetary rewards. Congress responded to these concerns by enacting the amusement and recreational exemption." Brock v. Louvers \& Dampers, Inc., 817 F.2d 1255, 1259 (6th Cir. 1987).

65 Brennan v. Yellowstone Park Lines, 478 F.2d 285, 288 (10th Cir. 1973).

66 See, e.g., Lara Queen Plaisance, Comment, You Want Fries with That Shake?: The Sexual Harassment of and Discrimination Against Teenage Workers, 77 UMKC L. REv. 227, 227-28 (2008) (discussing young workers' vulnerability to sexual harassment and discrimination on the job); Anthony J. Tucci, Note, Worthy Exemption? Examining How the DOL Should Apply the FLSA to Unpaid Interns at Nonprofits and Public Agencies, 97 IOWA L. REV. 1363 (2012) (discussing young workers' reluctance to enforce their 
show that senators were aware that many summertime workers were students, and that the exemption would therefore necessarily affect this group of workers. ${ }^{67}$ Meanwhile, during the debate over a failed set of amendments to the FLSA a year earlier, senators openly discussed the impact that the seasonal amusement and recreation exemption had on younger workers. Opponents of the 1965 proposal — which would have eliminated the minimum wage exemption for seasonal amusement and recreational establishments, while preserving an overtime exception ${ }^{68}$ - expressed concern that requiring seasonal employers to pay the minimum wage would result in the elimination of a number of jobs held by students. ${ }^{69}$ These senators successfully argued that these younger workers could afford to earn a lower wage due to their dependent status, justifying the preservation of the minimum wage exemption. ${ }^{70}$ So in light of this legislative history - as well as the FLSA's historic exclusion of other relatively less powerful, economically disadvantaged groups - the Tenth Circuit's speculation that there may have been an age-based motivation behind Section 213(a)(3) is plausible. ${ }^{71}$

Third, the legislative history suggests that Congress could have relaxed the exemption's seasonality test to "[give] ... a little more favorable break"72 to employers, but chose not to. Indeed, the failure of Senator Robertson's pro-employer receipts test proposal can be read

employment rights and vulnerability to exploitation).

67 In debate, Senator Cotton expressed the concern that, if resort hotels were not included in the Section 213(a)(3) exemption, then students employed by resorts during the summer would lose their jobs because hotels could not afford to pay them the FLSA-mandated minimum wage and overtime. Senator Yarborough replied, in defense of the exclusion of resort hotels from the exemption, "I do not feel that there is a danger that students will lose employment for the summer. Their productivity is high and their energy is great. I am sure that the Senator has had the experience which I have had with the summer interns." 112 CONG. REC. 20,595 (Aug. 25, 1966) (statements of Sens. Cotton and Yarborough).

68 H.R. REP. NO. 89-871, at 26 (1965) (describing a bill that "[r]epeals the minimum wage and overtime exemptions for such establishments [hotel, restaurant, motion picture, and recreational establishments; hospitals and related institutions] (except that seasonal resorts and seasonal recreational and amusement establishments maintain overtime exemptions)").

69111 CONG. REC. 21,830 (Aug. 25, 1965) (statement of Rep. Callaway) (describing a Georgia resort that "will not be able to employ any of these youngsters at the minimum wage because they are paying a lesser amount for these students who are not only unskilled but they are young children").

70 Id. (describing the students as earning "a part of their livelihood" from seasonal jobs).

71 See supra notes 31-36 and accompanying text.

72112 CONG. REC. 20,593 (Aug. 25, 1966) (statement of Sen. Robertson). 
as consistent with statements by members of Congress in 1966 about the need to expand, rather than contract the FLSA. The preamble to the House bill that introduced the 1966 amendments notes that "despite the [FLSA's] broad coverage terms ... there is great need for extending the present coverage of the Act to large groups of workers whose earnings today are unjustifiably and disproportionately low."73 The rejection of Senator Robertson's proposal might also be read as skepticism about waiving FLSA requirements for relatively lucrative businesses such as resort hotels. As a fellow senator asked Senator Robertson, "Is the Senator saying that a hotel that is affluent enough to charge a patron $\$ 60$ a day cannot pay a worker $\$ 50$ a week? Do I understand the Senator correctly?" 74 By enacting a stricter receipts test as a measure of seasonality, Congress chose to extend FLSA coverage to more categories of workers and limit the exemption's application to presumably less "affluent" categories of employers.

\section{Stages of A SeCtion 213(A)(3) ANalysis}

Despite these modest insights from the legislative history - or perhaps because of their modesty - courts have struggled to consistently apply Section 213(a)(3). ${ }^{75}$ In the relatively few cases that have addressed the exemption, ${ }^{76}$ courts have failed to adopt a consistent, clear standard for measuring seasonality, instead often considering a number of factors that are irrelevant to the exemption's focus on seasonal recreational or amusement employers. ${ }^{77}$ To remedy the confusion in the case law, the following Part proposes a simplified approach, rooted in the text of the statute and guided by its implementing regulations and legislative history. This new analytical

73 H.R. REP. NO. 89-1366, at 82 (1966).

74112 CONG. REC. 20,791 (Aug. 26, 1966) (statement of Sen. Pastore).

75 Brennan v. Texas City Dike \& Marina, Inc., 492 F.2d 1115, 1117 (5th Cir. 1974) ("If there is any unifying principle underlying the exemptions in the FLSA, it is not evident in the Act's words or its legislative history... . The absence of a unifying principle [behind the FLSA's exemptions] makes the exemptions' interpretation a difficult task."); see also infra Part II.A (describing problems with courts' identification of the establishment); infra Part III.A (describing courts' confused precedent applying the exemption to professional sports teams).

76 A Westlaw search for opinions that mention $\S 213(\mathrm{a})(3)$ reveals only thirtythree cases (excluding cases that generated more than one opinion) that addressed the exemption in more than passing language between the years 1972, the date of the earliest opinion, and January 2015.

77 See, e.g., infra note 121 (discussing the Tenth Circuit's analysis of a tourist company's operations in Brennan v. Yellowstone Park Lines, Inc., 478 F.2d 285, 287 (10th Cir. 1973)). 
framework consists of three steps: (1) identifying the relevant "establishment"; (2) determining the "amusement or recreational" nature of that establishment; and (3) evaluating seasonality by applying either the seven-month duration test to that establishment's operations or the receipts test to its revenue.

\section{A. Identifying the Establishment}

Courts that have considered Section 213(a)(3) often treat the analysis as having only two steps: "The establishment must be (1) seasonal and (2) recreational."78 These courts seem to assume that the "establishment" in question is simply the defendant named in the case, and then proceed to evaluate that defendant's amusement or recreational and seasonal character.

However, this commonly used approach creates problems when the defendant is engaged in different lines of business, some of which are amusement or recreational in nature, or some of which are seasonal, and some of which are not. How should courts approach, for example, a marina that sells boats, motors, and trailers year-round (a nonrecreational activity), but also provides seasonal dock access for boat launching (a recreational activity) ${ }^{79}$ Must the defendant's entire business be seasonal, or only the amusement or recreational functions? For that matter, must the entire business be devoted to the provision of amusement or recreational services?80 As discussed

78 Texas City Dike, 492 F.2d at 1117 ("The exemption contains two requirements. The establishment must be (1) seasonal and (2) recreational."); see also, e.g., Bridewell v. Cincinnati Reds, 68 F.3d 136, 138 (6th Cir. 1995) (requiring that the defendant "(1) must be an amusement or recreational establishment and (2) must not operate for more than seven months in a calendar year"); Ivanov v. Sunset Pools Mgmt. Inc., 567 F. Supp. 2d 189, 192 (D.D.C. 2008) ("[T]here are two elements to the amusement and recreational exemption: (1) the employer must demonstrate that it qualifies as an 'amusement or recreational establishment'; and (2) the employer must show either that it does not operate for more than seven months a year or that its average receipts for six months of the prior year were not more than a third of its average receipts for the other six months.").

79 See generally Texas City Dike, 492 F.2d at 1116 (describing varied functions of defendant marina).

80 These questions were anticipated in the debate in the House of Representatives over the 1966 FLSA amendments, during which Representative Udall asked, "[W]ould [the exemption] apply where you have one resort management running a souvenir and gift shop or general supply and grocery store, service station and garage and so forth, along with the hotel and restaurant - that is, all these allied activities under the one management. If all these activities are ancillary to a recreation activity which does meet the seasonality or average 6-month receipts criteria - if this is substantially all under one management and meets these criteria, would all of these activities be 
further in Part III, infra, this question has proved particularly vexing in cases involving professional sports teams, giving rise to conflicting precedent on the question of the seasonality of the teams' operations. ${ }^{81}$

Courts can avoid many of these problems by first identifying the relevant establishment(s) at issue in the case before proceeding to the amusement or recreation and seasonality questions. ${ }^{82}$ Not only does this threshold step allow courts to engage in a cleaner, more focused inquiry, but it is also consistent with Section 213(a)(3)'s text, which refers to "any employee employed by an establishment which is an amusement or recreational establishment." 83 The phrase, "which is an amusement or recreational establishment" modifies "an establishment," suggesting that the first task for the court is to find "an establishment" in the record, and then proceed with the remainder of the analysis. ${ }^{84}$

exempt[?]" 112 CONG. REC. 11,367 (May 25, 1966) (statement of Rep. Udall).

81 Compare Jeffery v. Sarasota White Sox, Inc., 64 F.3d 590, 596 (11th Cir. 1995) (holding that a baseball team was not required to pay overtime to a groundskeeper who worked at the stadium year-round because the team provided amusement only during its relatively short playing season), with Bridewell, 68 F.3d at 138-39 (holding on very similar facts to Jeffery that that year-round baseball stadium maintenance employees were entitled to overtime because the team continued to engage in business operations after the end of its playing season).

82 See Fair Labor Standards Act (Dep't of Labor Sept. 28, 2006) (Opinion Letter) [hereinafter Opinion Letter on FLSA, Sept. 28, 2006], available at 2006 WL 3227792 , at *1 (listing the first of three steps in the analysis of the exemption's application as identifying the relevant establishment).

8329 U.S.C. \& 213(a)(3) (2012).

84 As a technical matter, given that the exemption refers to "any employee employed by an establishment," the true first question should be "What entity is the plaintiffs employer?" However, this is a question relevant not only to the application of the exemption, but to the application of the FLSA as a whole. If the defendant feels that it is not properly named as a defendant - if, for purposes of the FLSA, the plaintiff was actually employed by a different entity - then the defendant has a separate argument to make in its defense, apart from the application of Section 213(a)(3), that draws on the long and well-established body of case law that defines "employee" and "employ" for purposes of the FLSA. See, e.g., Ivanov v. Sunset Pools Mgmt. Inc., 567 F. Supp. 2d 189, 194-96 (D.D.C. 2008) (reciting the standards for holding an entity accountable as an employer under the FLSA).

For purposes of the exemption itself, case law and regulations also distinguish between workers who are "employed in" a particular establishment and those who are "employed by" that establishment; only the latter category of workers are included. 29 C.F.R. \& 779.309 (2011) ("For example, if the manufacturer sends one of his employees to demonstrate to the public in a customer's exempt retail establishment the products which he has manufactured, the employee will not be considered exempt... since he is not employed by the retail establishment but by the manufacturer. The same would be true of an employee of the central offices of a chain-store organization who performs work for the central organization on the 
How, then, should a court identify the relevant establishment? While the FLSA's text does not define the term, its regulations provide some guidance. As a starting point, 29 C.F.R. $§ 779.23$ distinguishes between an "establishment," defined as "'a distinct physical place of business," and an "entire business or enterprise' which may include several separate places of business." 85 Another regulation, 29 C.F.R. $\S 779.303$, elaborates on the establishment-enterprise distinction:

The "enterprise"... may be composed of a single establishment. The term "establishment," however, is not synonymous with the words "business" or "enterprise" when those terms are used to describe multiunit operations. In such a multiunit operation some of the establishments may qualify for exemption, others may not. For example, a manufacturer may operate a plant for production of its goods, a separate warehouse for storage and distribution, and several stores from which its products are sold. Each such physically separate place of business is a separate establishment. In the case of chain store systems, branch stores, groups of independent stores organized to carry on business in a manner similar to chain store systems, and retail outlets operated by manufacturing or distributing concerns, each separate place of business ordinarily is a separate establishment. ${ }^{86}$

premises of an exempt retail outlet of the chain."); see also Harvey v. Dunlop, No. 73874, 1975 WL 1204, at*7 (W.D. Pa. Nov. 28, 1975) (citing Wage-Hour Op. Letter No. 760 (Jan. 17, 1968), CCH Lab. L. Rep. P 25,223.30 (1975) (concluding that the recreational or amusement exemption was not applicable to the employees of an independent janitorial service provided on racetrack premises)).

Meanwhile, if the employee works for more than one distinct establishment, then her entitlement to the minimum wage and overtime is determined on a per-workweek basis, depending on whether the establishment is exempt under all of the requirements of $\S 213(\mathrm{a})(3)$. If she works for exempt and non-exempt establishments during the same workweek, she is considered non-exempt, or entitled to the FLSA's benefits. 29 C.F.R. \& 779.311 (2011) ("[I]t may be stated as a general rule that if such an employer employs an employee in the work of both exempt and nonexempt establishments during the same workweek, the employee is not 'employed by' an exempt establishment during such workweek.").

8529 C.F.R. \& 779.23 (2011).

8629 C.F.R. \& 779.303 (2011); see also 29 C.F.R. \& 779.203 (2011) ("The coverage, exemption and other provisions of the [FLSA] depend, in part, on the scope of the terms employer, establishment, or enterprise... The term employer... includes, with certain stated exceptions, any person acting directly or indirectly in the interest of an employer in relation to an employee. The term establishment means a distinct physical place of business rather than an entire business or enterprise. The term enterprise . . . is roughly descriptive of a business rather than of an establishment 
Thus, under this pair of regulations, a "business" or "enterprise" may best be thought of as a legal entity, whereas an "establishment" is a physical one, defined with reference to the physical space it occupies. ${ }^{87}$ In this view, courts should treat each physically distinct outpost of a business as its own establishment for purposes of Section $213(\mathrm{a})(3) .88$

Other regulations complicate this simple line-drawing, however, contemplating the coexistence of multiple separate establishments in the same physical space. In such cases, 29 C.F.R. \& 779.305 states that

or of an employer although on occasion the three may coincide. The enterprise may consist of a single establishment (see § 779.204(a)) which may be operated by one or more employers; or it may be composed of a number of establishments which may be operated by one or more employers.").

In § 213(a)(3) cases, courts routinely cite regulations — such as 29 C.F.R. 779.303 - that were issued pursuant to the retail and service establishment exemption, in which the seasonal amusement or recreational exemption was initially included. Thus, examples given in some regulations and cases feature retail or service workers rather than recreational or amusement workers. Only one district court has questioned the application of these regulations and precedent to $\S 213(\mathrm{a})(3)$; all remaining courts have adopted the retail and service exemption regulations and case law without question. This article does the same. Compare West v. City of Fort Pierce, Fla., No. 0714335-CIV, 2008 WL 3270849, at *5 (S.D. Fla. Aug. 8, 2008) (distinguishing retail and service exemption cases; stating that "the Court was concerned with a different exemption than the one at issue in this case"), with Alvarez Perez v. Sanford-Orlando Kennel Club, Inc., 515 F.3d 1150, 1157-58 (11th Cir. 2008) (citing and relying on case law and regulations concerning the retail and service establishment exemption).

87 There is no requirement that an employer own the establishment at issue; leasing is sufficient. Jeffery v. Sarasota White Sox, Inc., 64 F.3d 590, 595 (11th Cir. 1995).

88 Many $\S 213(\mathrm{a})(3)$ cases reflect this reliance on an establishment's physical location. See, e.g., Alvarez Perez, 515 F.3d at 1157 (concluding that "when a part of a business complex seeks exemption as a separate establishment it must at least show that it has a physically separate place of business"); Chen v. Major League Baseball, 6 F. Supp. 3d 449, 460 (S.D.N.Y. 2014) ("FanFest was a sports event that was physically separate from the enterprise through which it was operated and controlled. In other words, the 'establishment' at issue here - as distinguished from the 'enterprise' that operated and controlled it — is defined by its discrete physical location."); Wright v. Adventures Rolling Cross Country, Inc., No. C-12-0982 EMC, 2013 WL 1758815, at *6 (N.D. Cal. Apr. 24, 2013) (finding that administrative office that was physically separate from the defendant's other activities was its own, non-exempt establishment); West, 2008 WL 3270849, at *6 (rejecting an attempt by the plaintiff, a theater employee, to treat a city-owned theater (exempt) and the city as a whole (nonexempt) as a single non-exempt establishment; stating, "Although the City certainly provides certain functions to the theatre as part of its ownership and control, the theatre is a distinct entity and it is undisputed that the theatre has a distinct physical location. Thus, the Court finds... that the theatre is the 'establishment' in this case and it is the distinct physical place of business and the City is entire business or enterprise"). 
an establishment should be considered separate under the FLSA if "(a) It is physically separated from the other activities; and (b) it is functionally operated as a separate unit having separate records, and separate bookkeeping; and (c) there is no interchange of employees between the units." 89 In Feagley v. Tampa Bay Downs, Inc., for example, the district court considered the status of a poker room that was contained within a racetrack facility. ${ }^{90}$ While both the poker room and the track provided amusement and recreation services, only the racetrack could satisfy the seasonality test. ${ }^{91}$ Unsurprisingly, the plaintiff, a poker dealer, argued that the poker room was its own separate, non-exempt establishment; the defendant argued that the two were part of the same, exempt whole. ${ }^{92}$ The court denied summary judgment to the defendant in light of 29 C.F.R. \& 779.305, noting unresolved questions of material fact regarding the establishment issue, such as "whether Silks Poker Room dealers are subject to the same managerial control as are other employees of Tampa Bay Downs," whether the poker room and race track "were treated as distinct and autonomous economic units within the business," the "markedly different business risks" borne by the two entities, the state regulations to which they were subject, the segregation of the two sets of receipts, and the level of "interchange" between the poker room dealers and other race track employees. 93

Another regulation introduces a fourth possible establishment configuration: a single establishment consisting of multiple separate physical locations. This regulation, 29 C.F.R. \& 1620.9, was issued by the U.S. Equal Employment Opportunity Commission ("EEOC") to interpret the Equal Pay Act ("EPA") - which prohibits sex

8929 C.F.R. \& 779.305 (2011). On the question of the interchange of employees, the regulation notes, "The requirement that there be no interchange of employees between the units does not mean that an employee of one unit may not occasionally, when circumstances require it, render some help in the other units or that one employee of one unit may not be transferred to work in the other unit. The requirement has reference to the indiscriminate use of the employee in both units without regard to the segregated functions of such units." Id.

90 Feagley v. Tampa Bay Downs, Inc., No. 8:11-CV-564-EAK-MAP, 2012 WL 2178857, at *5-6 (M.D. Fla. June 13, 2012)

91 Id. at *4 (noting that the race track satisfied the receipts test for seasonality).

92 Id. at *2 ("Tampa Bay Downs argues that it is absolutely exempt ... because it satisfies the so-called amusement and recreational establishment exemption of the federal Fair Labor Standards Act.... Feagley, for his part, argues that Tampa Bay Downs and the Silks Poker Room are actually two separate establishments for purposes of FLSA exemptions, and that the exemption is therefore inapplicable to him and his cohorts.").

93 Id. at *5-6. 
discrimination in pay - enacted as part of the FLSA.94 Though developed in the EPA context, courts have applied the EEOC's "establishment" reasoning and regulation in Section 213(a)(3) cases. ${ }^{95}$

According to 29 C.F.R. \& 1620.9, though "each physically separate place of business is ordinarily considered a separate establishment," in "unusual circumstances" courts may unite a defendant's physically separate locations and consider them together as a single establishment. ${ }^{96}$ The regulation provides an illustration of such "unusual circumstances": a business operates at multiple distinct physical locations, but in which "a central administrative unit may hire all employees, set wages, and assign the location of employment; employees may frequently interchange work locations; and daily duties may be virtually identical and performed under similar working conditions." 97 The Fifth Circuit applied this regulation in Brennan v. Goose Creek Consolidated Independent School District, holding that female janitors suing for equal pay could treat the school district as a

94 The definition of "establishment" is important to the EPA analysis because the statute prohibits pay discrimination on the basis of sex within an "establishment." 29 U.S.C. § 206(d)(1) (2012) ("No employer having employees subject to any provisions of this section shall discriminate, within any establishment in which such employees are employed, between employees on the basis of sex by paying wages to employees in such establishment at a rate less than the rate at which he pays wages to employees of the opposite sex in such establishment for equal work on jobs the performance of which requires equal skill, effort, and responsibility, and which are performed under similar working conditions.").

95 See Doe v. Butler Amusements, Inc., 71 F. Supp. 3d 1125, 1134 n.5 (N.D. Cal., 2014) ("In short, Defendant's assertion that 29 C.F.R. § 1620.9 is applicable only to the Equal Pay Act and does not offer guidance as to the meaning of 'establishment' in the context of overtime and minimum wage claims asserted under the FLSA has no merit.").

9629 C.F.R. § 1620.9 (1981).

97 Id.; see also Paddell v. Goodyear Tire \& Rubber Co., No. 79-2303-M, 1979 WL 1805, at *3 (W.D. Tenn. Dec. 31, 1979) (relying on the remedial nature of the EPA, as part of the FLSA, to hold that multiple separate stores in a retail chain were part of a single establishment); cf. Shultz v. Hasam Realty Corp., 316 F. Supp. 1136, 1142-43 (S.D. Fla. 1970) ("[T]he Diplomat clearly consists of a single establishment within meaning of the [FLSA]. Four of the five main facilities are on physically contiguous parcels of land. The Presidential Country Club and Golf Course is located some five miles from the other buildings, but only because the price of land at the time of its construction made it economically unfeasible for the Diplomat to provide its guests with additional golf facilities closer to the main hotel units. No separate books and records are kept for the various facilities. The general accounting department maintains payroll, financial, and accounting records for all Diplomat properties. Nor are employees hired to work solely in one of the five units. Hiring is done through a central office, and employees are interchanged between the various facilities, as needed."). 
whole - rather than the individual schools where they worked - as the relevant establishment under the EPA. ${ }^{98}$ Important to the court's analysis were the facts that "the central administration of the school district (not the principals of the [individual] schools) hired the janitors, determined their wages, assigned them to the school building in which they were to work, and sometimes switched their assignments from one building to another." Moreover, the court emphasized the facts that "the work schedule and the janitors' daily duties [were] controlled to a large extent by the central administrators [and did] not differ from building to building." 99

Taking these regulations together, then, a court may be required to decide among four potential visions of the establishment in a Section 213(a)(3) case: (1) a single location housing a single establishment; (2) a single location housing multiple establishments; (3) multiple locations consisting together of a single establishment; and (4) multiple locations consisting separately as multiple establishments. Plaintiffs and defendants may argue, variously, to join or split locations, depending on which position allows the application or avoidance of the exemption.

In choosing among competing establishment configurations, courts should adopt the "basic presumption," derived from 29 C.F.R. \& 779.23 and 29 C.F.R. \& 779.303, that "each such physically separate place of business is a separate establishment." 100 However, courts must also draw "establishment" lines in a way that limits the applicability of Section 213(a)(3). This is because the FLSA is a remedial statute and, as such, must be interpreted in the broadest possible manner, with any exemptions construed narrowly. ${ }^{101}$ So, in some cases, a court may

98 Brennan v. Goose Creek Consol. Indep. School Dist., 519 F.2d 53, 56 (5th Cir. 1975).

99 Id.

10029 C.F.R. § 779.303 (2011); The Equal Pay Act Interpretations, 51 Fed. Reg. 29816, 29817 (Aug. 20, 1986).

101 As one court has observed, "The one strong thread running consistently through the great majority of these cases is that the courts have construed 'establishment' so as to preclude application of the exemption. ... The regulations of the Labor Department ... show clearly that the Department defines 'establishment' so as to use it as a tool to obtain coverage and limit the exemption." Dunlop v. N.H. Jockey Club, Inc., 420 F. Supp. 416, 421 (D.N.H. 1976). See also A.H. Phillips, Inc. v. Walling, 324 U.S. 490, 493 (1945) ("The Fair Labor Standards Act was designed "to extend the frontiers of social progress' by 'insuring to all our able-bodied working men and women a fair day's pay for a fair day's work.' Any exemption from such humanitarian and remedial legislation must therefore be narrowly construed, giving due regard to the plain meaning of statutory language and the intent of Congress. To extend an exemption to other than those plainly and unmistakably within its terms 
need to look beyond physical location in order to give full effect to the FLSA's remedial purpose. In performing this analysis, the First Circuit has advised courts "that a multi-faceted approach aimed at determining the integrity of separation between business units is in order... in contrast to single-minded reliance upon any one factor such as control, ownership or "physical location."'102 The EEOC has also advocated for this totality of the circumstances approach, emphasizing that courts should be allowed "a measure of flexibility whenever called for by the facts of a given case ... [as] certain factual situations may call for a restricted use of the term ["establishment"] while others may call for an expanded use." 103

\section{B. Determining the Establishment's Amusement or Recreational Status}

Once the relevant establishment has been identified, the next step is to determine its "amusement or recreational" status. ${ }^{104}$ The FLSA and

and spirit is to abuse the interpretative process and to frustrate the announced will of the people.") (citation omitted); Brennan v. Texas City Dike \& Marina, Inc., 492 F.2d 1115,1117 (5th Cir. 1974) ("The ground rules for interpreting and applying FLSA exemptions disfavor the employer.").

102 Marshall v. N.H. Jockey Club, Inc., 562 F.2d 1323, 1330-31 (1st Cir. 1977) ("[W]e think it appropriate to proceed beyond the regulation and look more broadly into "the integrity of the economic . . . and functional separation between the business units."'); see also Mitchell v. T.F. Taylor Fertilizer Works, Inc., 233 F.2d 284, 286 (5th Cir. 1956) (considering "functional as well as geographical separation" in defining an establishment); West v. City of Fort Pierce, Fla., No. 07-14335-CIV, 2008 WL 3270849 , at $* 5$ (S.D. Fla. Aug. 8, 2008) (describing the difference between situations in which it is "logical to treat the different parts of... businesses as separate establishments" and those in which "the different entities [are] clearly parts of an inseparable whole").

103 The Equal Pay Act Interpretations, 51 Fed. Reg. at 29817; see also Montalvo v. Tower Life Bldg., 426 F.2d 1135, 1145 (5th Cir. 1970) ("When business activities of a single enterprise take place within a single distinct physical place of business, for purposes of coverage under the [FLSA] the employer should not be allowed to escape coverage for some of the employees involved by arguing that its business activities are separated into separate 'establishments' along functional lines."). Compare Harvey v. Dunlop, No. 73-874, 1975 WL 1204, at *6 (W.D. Pa. Nov. 28, 1975) (rejecting a defendant's attempt to claim the exemption by trying to unite multiple, physically separate, non-exempt establishments (horse breeding and training facilities) with other, exempt establishments (race tracks) into one exempt whole to which the FLSA would not apply), with Doe v. Butler Amusements, Inc., 71 F. Supp. 3d 1125 (N.D. Cal. 2014) (declining to grant summary judgment to the defendants, who had asked the court to consider multiple different traveling carnival sites as separate, exempt establishments).

104 See Opinion Letter on FLSA, Sept. 28, 2006, supra note 82, at *2 (explaining that "[t]he second step in applying section 13(a)(3) is to determine whether each establishment qualifies as 'amusement or recreational'"). 
its regulations do not define these terms, and the definition offered by the Eleventh Circuit - "[a] recreational establishment" is one that "sell[s] recreation or entertainment as its "principal activity" 105 — is unhelpfully circular. The Oxford Dictionary, in turn, defines "amusement" to mean "[ $\mathrm{t}]$ he pleasurable occupation of the attention, or diversion of the mind"106; "recreation" is defined as a "pleasant occupation, pastime or amusement." 107

The exemption's legislative history provides some direction by listing some of the types of establishments that would be exempt under the provision, including "amusement parks, carnivals, circuses," and those providing entertainment in the form of "sports events, parimutuel racing, sport boating or fishing" to the public. ${ }^{108}$ Moreover, the debate recounted above between Senators Robertson and Yarborough over the inclusion of resort hotels within the exemption also sheds some light on the applicability of the exemption. ${ }^{109}$ There, Senator Robertson proposed extending the exemption "not to tourist hotels, not to hotels in any of the cities, not to hotels in industrial areas, but to a resort hotel which can qualify as a recreational institution."110 In particular, he cited as markers of a hotel's recreational character its provision of activities such as golf, horse riding, tennis, fishing, skiing, and skeet shooting, as opposed to convention hotels whose sole purpose is to host meetings. ${ }^{111}$

Importantly, the inquiry here does not focus on the plaintiffs own specific job duties, but rather the "principal activity" of the establishment employing the worker. ${ }^{112}$ An accountant employed by

\footnotetext{
105 Mann v. Falk, 523 F. App'x. 549, 552 (11th Cir. 2013).

106 Amusement, THE COMPACt Edition OF THE OXFord ENGLiSH Dictionary 74 (1971).

107 Recreation, Id. at 2447.

108 H.R. ReP. NO. 89-871, at 51 (1965).

109 See supra notes 52-62 and accompanying text.

110112 CONG. REC. 20,593 (Aug, 25, 1966) (statement of Sen. Robertson).

111 Id.

112 Several courts have mistakenly suggested that the applicability of $\S 213(\mathrm{a})(3)$ should hinge upon whether the particular employee-at-issue's job duties are themselves amusement or recreational in nature. See Brennan v. Six Flags Over Georgia, Ltd., 474 F.2d 18, 19 (5th Cir. 1973) ("It is the character of the work, not the source of the remuneration, that controls."); Hodgson v. Six Flags Over Georgia, Ltd., No. 14876, 1972 WL 945, at *3 (N.D. Ga. Aug. 8, 1972) ("The designation given such employees by defendants is not controlling; it is the nature of the work performed by such employees which is controlling."). However, a majority of courts have instead held that the nature of the individual's work is irrelevant, concluding instead that the applicability of the exemption depends solely on the character of the establishment's operations as a whole. See, e.g., Hamilton v. Tulsa Cnty. Pub. Facilities Auth., 85 F.3d 494, 497 (10th Cir. 1996) ("By its own terms, § 213(a)(3) of the FLSA exempts
} 
an otherwise exempt water park would be covered by Section 213(a)(3), for example, even though the accountant does not provide any amusement or recreational related services herself. Similarly, a lifeguard at a non-exempt hotel swimming pool would be entitled to the protections of the FLSA, even though she is employed in what traditionally would be considered a recreational position.

Along these lines, the establishment must provide recreation or amusement as its "principal activity." 113 In cases where the establishment's principal activity is in dispute, courts should examine the establishment's sources of revenue, and in particular discern whether the establishment generates the majority of its revenue from recreational or non-recreational sources. For instance, in Brennan $v$. Texas City Dike \& Marina, ${ }^{114}$ the Fifth Circuit considered whether a lake marina was an amusement or recreational establishment. Although the marina did tailor its business toward customers engaging in recreational boating activities, the court nevertheless emphasized the fact that fifty-seven percent of the marina's revenue came from boat sales. ${ }^{115}$ Consequently, the court held that the marina was not a recreational establishment because too large a percentage of its revenue came from non-recreational, commercial activities. ${ }^{116}$

employees employed by amusement or recreational establishments; it does not exempt employees on the basis of the work performed at an amusement or recreational establishment. It is the character of the revenue producing activity which affords the employer the protection of the exemption."); McMillan v. Boy Scouts of Am. - Aloha Council, No. 11-00430-SOM-BMK, 2012 WL 2282539, at *5 (D. Haw. June 15, 2012) ("Rather than focusing on the nature of the work, the applicable federal regulations state that the exemption 'depend[s] on the character of the establishment."'); Gibbs v. Montgomery Cnty. Agric. Soc'y, 140 F. Supp. 2d 835, 843-44 (S.D. Ohio 2001) ("Finally, the Court rejects Gibbs' argument that it should focus on the work that he performed, rather than the principal activities of the Defendant, when determining the applicability of the $\S 213($ a)(3) exemption."). Indeed, this view is consistent with both the statutory text and the applicable federal regulation. Section 213(a)(3) itself specifically states that "any employee employed by" a seasonal amusement or recreational establishment is exempt from the minimum wage and overtime laws. 29 U.S.C. \& 213(a)(3) (2012). Meanwhile, 29 C.F.R. \& 779.302 clarifies that the exemptions set forth in the FLSA "depend on the character of the establishment by which an employee is employed.... Therefore, if the establishment meets the tests enumerated in these sections, employees 'employed by' that establishment are generally exempt.” 29 C.F.R. \& 779.302 (1999).

113 Mann v. Falk, 523 F. App'x. 549, 552 (11th Cir. 2013).

114492 F.2d 1115 (5th Cir. 1974).

$115 \mathrm{Id}$. at 1116 ("[T]he marina derived fifty-seven percent of its income from selling boats, motors, and trailers.").

116 Id. at 1119-20 ("[T]he marina's principal activity is selling expensive recreational hardware. Therefore we conclude the marina is ineligible for exemption 
Such a focus on revenue is also consistent with the approach proposed by the U.S. Department of Labor ("DOL") in 2004 in Chao v. Double JJ Resort Ranch. ${ }^{117}$ Proceeding on the assumption that the entire resort constituted a single establishment at issue in the case, ${ }^{118}$ the DOL - the plaintiff in the suit - proposed an "income test" to determine whether the resort's "principal activity" was the selling of recreational activities (horseback riding and paddle boating, for example) or non-recreational activities like the operation of a gas station. ${ }^{119}$ Ultimately, the Sixth Circuit concluded that adopting such a test was unnecessary in the case, believing that "common sense compel[s] our finding that Double JJ is not in the recreation business" in light of its "primary purpose [being] to sell foods and rent beds." 120

Thus, when the amusement or recreational character of an establishment is in doubt, courts should examine the percentage of revenue coming from amusement or recreational operations. If a majority of that revenue is derived from the provision of amusement or recreational services, then the establishment would satisfy the second prong of this article's proposed three-part test under Section 213(a)(3). If the establishment's non-recreational operations generate a majority share of its revenue, however, then the establishment would lack the requisite "amusement or recreational" status, and would not qualify for an exemption under Section 213(a)(3). ${ }^{121}$

as an amusement or recreational establishment.").

117375 F.3d 393 (6th Cir. 2004).

118 As later noted by the Chao court itself, the resort in question likely constituted multiple separate establishments when properly analyzed. See id. at 398 ("[W]e cannot, on this record, declare that Double JJ is one establishment and thus wholly subject to the Act.").

119 Id. at 398 ("The Secretary asks that we adopt an 'income test' to guide our analysis, but we do not think it necessary to do so in this case.").

$120 \mathrm{Id}$.

121 If an establishment's "principal activity" is not the provision of amusement or recreation, then it will fall outside the exemption, even if its operations are linked to and help support another establishment's provision of amusement or recreational services. For example, in Brennan v. Yellowstone Park Lines, Inc., 478 F.2d 285, 287 (10th Cir. 1973), the Tenth Circuit divided the company overseeing tourist operations at Yellowstone National Park into multiple separate establishments, concluding that the company's accounting, marketing, and maintenance operations were not amusement or recreational in nature, and therefore not entitled to protection under the exemption. Id. at 290. 


\section{Evaluating the Seasonal Nature of the Establishment}

Finally, assuming the relevant establishment is primarily engaged in amusement or recreational operations, a court must consider whether it operates on a seasonal basis. ${ }^{122}$ An establishment can satisfy Section 213(a)(3)'s seasonality requirement based on either (A) the duration of its operations or (B) the timing of its receipt of revenue.

\section{Duration of the Establishment's Operations}

First, under Section 213(a)(3)(A), an establishment will be considered seasonal if "it does not operate for more than seven months in any calendar year." 123 Assuming the court has properly identified the establishment (as discussed in Part II.A above), its compliance with this provision should be relatively easy to determine based simply on the number of months that it was open to the public during the relevant year(s) in question. ${ }^{124}$ So, for example, a water park that is only open for business seven or less months per year would generally satisfy subsection (A)'s seasonal duration requirement, while a park open eight or more months per year would not.

This would be true even if some of the water park's employees worked more than seven months per year. As the DOL's Wage and Hour Division explained in an opinion letter considering the applicability of the exemption to lifeguards employed at a public beach:

The fact that some of the lifeguards [may] work more than seven months in the year maintaining [beach] equipment would not serve to deny the exemption under section 13(a)(3), provided the establishment (the beach) is not open

122 Opinion Letter on FLSA, Sept. 28, 2006, supra note 82, at *2 (stating that "[t]he final step in applying section 13(a)(3) is to determine whether each [establishment] meets the requirements of section $13(\mathrm{a})(3)(\mathrm{A})$ regarding the duration of [its] operation or section 13(a)(3)(B) regarding [its] receipts").

12329 U.S.C. \& 213(a)(3)(A) (2012).

124 Notably, subsections (A) and (B) of Section 213(a)(3) differ with respect to how they each frame the relevant year in question. In subsection (A), Congress chose the phrase "in any calendar year," while in subsection (B), discussed infra Part II.C.2, it said "during the preceding calendar year." Compare id. (not limiting the relevant time period to the previous calendar year), with 29 U.S.C. § 213(a)(3)(B) (limiting the relevant time period to only the "preceding calendar year"). Thus, it appears that the applicability of subsection (A) should be determined based on the number of months the business was open to the public during the calendar year in which the alleged violation occurred, while the applicability of subsection (B) is based on the receipts the business received the year before the alleged FLSA violation arose. 
as a recreational facility ... for more than seven months in any calendar year. ${ }^{125}$

Similarly, an amusement park open to the public six months per year would still properly satisfy subsection (A) even if it employed someone on a year-round basis to maintain its landscaping. Indeed, a DOL Fact Sheet regarding Section 213(a)(3) specifies that "[i]f an establishment engages only in such activities as maintenance operations or ordering supplies during the 'off season' it is not considered to be operating for purposes of the exemption." 126

Thus, assuming that the court has correctly identified the proper establishment in question, applying subsection (A)'s seasonal duration requirement will typically be relatively straightforward. Assuming that the establishment at issue engages in only minimal off-season operations, it will qualify for protection under subsection (A) if it is only open to the public for seven months or less per year; otherwise, the establishment will presumptively remain subject to the FLSA.

\section{Receipt of the Establishment's Revenues}

If an establishment does not meet Section 213(a)(3)(A)'s seasonal duration test, it may nevertheless claim exempt status under subsection (B) if, "during the preceding calendar year, its average receipts for any six months of such year were not more than $331 / 3$ per centum of its average receipts for the other six months of such year." 127 In other words, for example, if an establishment receives an average of at least three times as much income between the months of April and September as it averages for October through March, it will qualify as a seasonal establishment despite operating on a year-round

125 Fair Labor Standards Act (Dep't of Labor Jan. 24, 1975) (Opinion Letter), available at 1975 WL 40933 (quoted in Fair Labor Standards Act (Dep't of Labor Jan. 14, 2009) (Opinion Letter), available at 2009 WL 648997, at *2). DOL opinion letters "are normally entitled to a high degree of deference, [but] they are not binding on the court if they are plainly erroneous or are inconsistent with the regulations they interpret." Imada v. City of Hercules, 138 F.3d 1294, 1297 (9th Cir. 1998).

126 U.S. Dep't of Labor, Wage \& Hour Div., Fact Sheet \#18: Section 13(A)(3) EXEMPTION FOR SEASONAL AMUSEMENT OR RECREATIONAL ESTABLISHMENTS UNDER THE FAIR LABOR STANDARDS ACT (FLSA) (2008), available at http://www.dol.gov/whd/ regs/compliance/whdfs18.pdf. A DOL fact sheet "is not binding law, particularly where... it runs afoul of the binding authority." Joseph v. Nichell's Caribbean Cuisine, Inc., 862 F. Supp. 2d 1309, 1313 n.l (S.D. Fla. 2012). Courts, however, are free to treat a fact sheet as persuasive authority if they agree with the analysis contained therein. See id.

12729 U.S.C. $\S 213(\mathrm{a})(3)(\mathrm{B})$. 
basis. ${ }^{128}$ This provision allows businesses with a "sharp, but short, peak [season] to remain unhindered by the FLSA's [minimum wage and] overtime requirements." 129

When analyzing an establishment's receipts under subsection (B), courts employ a so-called "cash" method — as opposed to an "accrual" method - of accounting. ${ }^{130}$ Under the cash method, the actual date upon which a business receives its income is determinative. ${ }^{131}$ So, for instance, if a private golf course were to receive seventy-five percent or more of its annual revenue in the form of membership dues between the months of November and March, it would be exempt from the FLSA under the cash method of accounting even if the course operates on a year-round basis. ${ }^{132}$ In contrast, under an accrual method of accounting, income would not be considered earned until the services being purchased had actually been proffered to the customer. ${ }^{133}$ Thus, under such an approach, the private golf course above would see its membership dues prorated across twelve months, disqualifying it from coverage under subsection (B).

This focus on the date that payment is received, rather than when it actually accrues to the business, is consistent with subsection (B)'s use of the term "receipt."134 Black's Law Dictionary defines "receipt" to mean the "[a]ct of receiving; also, the fact of receiving or being received." 135 Thus, because Congress selected a word focused on the actual acceptance of income, rather than the date on which it is ultimately considered earned, courts have reasoned that applying a

128 To be clear, the months in question need not be sequential. If a business can show that its average revenues for any six months in a year - say, January, March, May, July, September, and November - satisfy the receipts test then it will be considered an exempt establishment.

129 Derrig v. Rich Harvest Farms Co., No. 08-C-7193, 2010 WL 375188, at *2 (N.D. Ill. Feb. 1, 2010).

130 See, e.g., Bridewell v. Cincinnati Reds, 155 F.3d 828, 830 (6th Cir. 1998) (explaining the two accounting methods and affirming the district court's choice of the cash over accrual method); Hays v. City of Pauls Valley, 74 F.3d 1002, 1006 (10th Cir. 1996) (refusing to pro rate defendant's income, as under the accrual method).

131 See Bridewell, 155 F.3d at 830 ("Under the cash method of accounting, a company records money as income the moment it is received.").

132 See Hays, 74 F.3d at 1006 (refusing to prorate golf course dues received in a three-month period over a full calendar year).

133 See Bridewell, 155 F.3d at 830 ("[T] he accrual method of accounting does not record money as income until the underlying obligation (e.g., delivery of the product, performance of the service, etc.) has taken place.").

13429 U.S.C. § 213(a)(3)(B) (2012).

135 Black's LaW Dictionary 1268 (6th ed. 1990). 
cash method of accounting is appropriate under subsection (B).136 Nevertheless, some have criticized the focus on the date that revenue is received, contending that "the accrual method of accounting best reflects the operation of" many recreational businesses. 137 While this may be true, the majority rule's focus on the actual date that revenue is received is reasonable given Section 213(a)(3)'s emphasis on the seasonal duration of the establishment's operations. ${ }^{138}$ Indeed, the fact that a business receives a disproportionate share of its revenue in a relatively short period of time tends to suggest that its operations are, effectively, seasonal in nature. ${ }^{139}$

Consequently, so long as a recreational establishment can show a six-month low period during which its average receipts are, at most, only one-third of the other six month's average receipts, it will be exempt under Section 213(a)(3)(B). If not, the establishment remains subject to the FLSA.

\section{Professional Sports Teams AND Section 213(A)(3)}

The status of professional sports teams as seasonal amusement or recreational establishments under Section 213(a)(3) has generated a sizeable percentage of the exemption's existing precedent. ${ }^{140}$ The application of the FLSA remains an important issue for the industry, as at least eleven different lawsuits alleging violations of the minimum wage and overtime laws have been filed against sports teams in 2014

136 See, e.g., Bridewell, 155 F.3d at 830 (adopting the district court's holding that "the statute speaks in terms, not of income, but in terms of receipts").

137 Id.

138 See id. at 832-33 (Cole, J., concurring) (arguing that "I believe that it is quite logical that Congress chose not to exempt an organization like the Reds from paying an employee like Daisy S. Pearl an additional $\$ 2.75$ per hour above her regular rate of $\$ 5.50$ per hour for overtime hours, because the Reds clearly benefit financially by receiving significant amounts of its revenue in the off-season").

139 See Liger v. New Orleans Hornets NBA Ltd. P'ship, 565 F. Supp. 2d 680, 686 (E.D. La. 2008) ("The FLSA's 'receipt' test is logical, fair and an accurate assessment of the year round activity of an organization.").

Admittedly, this focus on the date that a business receives its revenue may be susceptible to some manipulation, as it is possible a business could strategically require customers to make all payments within a six-month period of time in order to qualify the business as seasonal under $\S 213(\mathrm{a})(3)(\mathrm{B})$.

140 Of the thirty-three cases filed before January 2015 that addressed $\S 213$ (a)(3) substantively, five of those cases involved the professional sports industry. See supra note 76; see also Jeffery v. Sarasota White Sox, Inc., 64 F.3d 590, 592 (11th Cir. 1995); Bridewell v. Cincinnati Reds, 68 F.3d 136, 137 (6th Cir. 1995); Chen v. Major League Baseball, 6 F. Supp. 3d 449, 451 (S.D.N.Y. 2014); Liger, 565 F. Supp. 2d at 681-82; Adams v. Detroit Tigers, Inc., 961 F. Supp. 176, 177 (E.D. Mich. 1997). 
and 2015.141 However, because prior courts in sports team cases have often failed to properly identify the establishment at issue conflating the team's game-day and general business operations - the existing precedent in this area is both inconsistent and confused. As a result, additional clarity in this area of the law is needed.

\section{A. Existing Precedent Applying Section 213(a)(3) to Professional Sports Teams}

While prior courts applying the exemption agree that professional sports teams provide amusement services, they disagree as to whether the teams operate on a seasonal basis. On the one hand, a sports team's actual provision of amusement to the public typically occurs only during its playing season, which may last seven months or less, satisfying subsection (A). ${ }^{142}$ On the other hand, a team's general business operations usually continue year-round, with a significant number of its ticket sales, sponsorship agreements, and player transactions occurring during the off-season. ${ }^{143}$ As a result, some courts have focused solely on the length of the team's playing season when applying subsection (A), while others have emphasized the entirety of the team's business operations.

For example, in Jeffery v. Sarasota White Sox, Inc., ${ }^{144}$ the Eleventh Circuit held that a minor league baseball team was exempt from the FLSA's minimum wage and overtime provisions based on the length of its playing season. The court rejected a claim for overtime by the team's grounds keeper, noting that the team's playing season lasted only five months - from April through August - and thus fell below Section 213(a)(3)(A)'s seven-month seasonality threshold.145 Even though the grounds keeper continued to maintain the team's playing facility during its off-season - and thus himself worked more than seven months per year - the court emphasized that the proper focus was "on [the] length of the Defendant's seasonal operation[s]"

141 See supra notes 1, 6-9 \& 11-13 (listing seven lawsuits by NFL cheerleaders, two lawsuits by minor league baseball players, one lawsuit by MLB scouts, and one lawsuit by an NBA team intern).

142 See infra notes 193-205 and accompanying text.

143 See James T. Reese et al., National Football League Ticket Transfer Policies: Legal and Policy Issues, 14 J. Legal AspeCts SPORT 163, 165 (2004) (noting that most season ticket sales occur during the off-season).

14464 F.3d 590 (11th Cir. 1995).

145 Id. at 596 ("Defendant's operation at the baseball complex in Sarasota lasts approximately five months each year which is two months less than the seven month period afforded under 29 U.S.C. \& 213(a)(3).”). 
themselves, since Section "213(a)(3) does not require Defendant to completely shut down or to terminate every employee at the end of each baseball season."146

In contrast, the Sixth Circuit considered the entirety of a sports team's business operations when applying subsection (A) in Bridewell v. Cincinnati Reds. ${ }^{147}$ In Bridewell, a group of five stadium maintenance employees sued MLB's Cincinnati Reds for unpaid overtime. ${ }^{148}$ In response, the team contended that it was exempt insofar as its regular playing season lasted seven months or less (from April through lateSeptember or early-October). ${ }^{149}$ Although the district court had initially ruled in the Reds' favor, concluding that each of the team's home games was a separate, single-day establishment under subsection (A),150 the Sixth Circuit reversed.151 The appellate court stressed that exemptions under the FLSA should be construed narrowly, ${ }^{152}$ and determined that "the duration of the Reds' overall operation," rather than the length of the team's playing season, formed the relevant inquiry under subsection (A). ${ }^{153}$ The court concluded that even though the team only provided amusement to its customers seven months per year, it actually operated year-round, as evidenced by the fact that the team employed 120 people twelve months per

146 Id.

147 Bridewell v. Cincinnati Reds, 68 F.3d 136, 139 (6th Cir. 1995).

148 See id. at 138 n.1 (6th Cir. 1995) (explaining that the five plaintiffs were suing on their own behalf and on the behalf of other "maintenance and cleaning coworkers"); Bridewell v. Cincinnati Reds, No. C-1-93-203, 1994 WL 866091, at *1 (S.D. Ohio March 24, 1994).

149 See Bridewell, 68 F.3d at 138 (summarizing defendant's argument); Bridewell, 1994 WL 866091, at *1.

150 Bridewell, 1994 WL 866091, at *1 ("Each game played by The Reds at Riverfront Stadium therefore constitutes a sporting event. Accordingly, the Magistrate Judge correctly concluded that The Reds qualify for the Amusement and Recreational Establishment exemption for the years 1991, 1992, and 1993."). As discussed infra, the district court's determination that each individual game was a separate establishment was erroneous given the applicable regulations' focus on physical places of business. See infra note 163.

151 Bridewell, 68 F.3d at 139.

152 Id. at 138 ("The Reds have the burden of establishing entitlement to the exemption, which we construe narrowly.").

153 Id. 
year. ${ }^{154}$ As a result, the Sixth Circuit concluded that the Reds were not exempt under subsection (A). ${ }^{155}$

Similarly, the court in Liger $v$. New Orleans Hornets rejected an NBA team's attempt to claim exempt status under Section 213(a)(3)(A).156 Liger involved a claim for unpaid overtime by former ticket sales and fan relations employees of the New Orleans Hornets. ${ }^{157}$ Relying on the Sixth Circuit's decision in Bridewell, 158 the district court determined that the Hornets were, in effect, a year-round operation, and thus ineligible for protection under subsection (A). ${ }^{159}$ In particular, the court emphasized the fact that the Hornets' season could potentially last as long as nine months per year once potential pre- and postseason games were factored in. ${ }^{160}$ Moreover, as in Bridewell, the court noted that the team employed more than 100 people on a yearround basis. ${ }^{161}$ Consequently, the court concluded that the team was not a seasonal establishment, and thus not exempt from the FLSA. ${ }^{162}$

The conceptual differences between the Jeffery, Bridewell, and Liger courts regarding the duration of a sports team's operations underscore the importance of properly identifying the relevant establishment at issue in the suit. In none of these three cases did the deciding court attempt to precisely define the establishment in question. ${ }^{163}$ Instead,

154 Id. at 139 ("While a truly seasonal business that employs an insignificant number of workers year-round could conceivably qualify for the exemption, the fact that the Reds employ 120 year-round workers compels the conclusion that they 'operate' year-round.").

155 Id. ("Because the Reds operate for more than seven months in a calendar year, they were not entitled to summary judgment based upon 29 U.S.C. \& 213(a)(3).").

156 Liger v. New Orleans Hornets NBA Ltd. P'ship, 565 F. Supp. 2d 680 (E.D. La. 2008).

157 Liger v. New Orleans Hornets NBA Ltd. P'ship, No. 05-1969, 2006 WL 2850157, at *1 (E.D. La. Oct. 04, 2006).

158 Liger, 565 F. Supp. 2d at 684 ("The Plaintiffs' reliance on Bridewell is more appropriate.").

159 Id. ("[T]he Court finds that the Hornets are a year-round operation, and thus, cannot qualify for the exemption under 29 U.S.C. \& 213(a)(3)(A).").

160 Id. ("[T] he NBA regular season typically begins in October and ends in April; in combination with pre-season and post-season games, the Hornets have the opportunity to participate in games for nine months each year."). In addition, the court also noted that the team participated in each June's NBA Draft, and thus "operate[d] in the summer even when they do not make the playoffs." Id.

161 Id. "The Hornets admit that they employ over 100 personnel in year round positions.").

162 Id. ("[T]he Court finds that the Hornets are a year-round operation, and thus, cannot qualify for the exemption under 29 U.S.C. \& 213(a)(3)(A).").

163 See generally Jeffery v. Sarasota White Sox, Inc., 64 F.3d 590 (11th Cir. 1995); Bridewell v. Cincinnati Reds, 68 F.3d 136 (6th Cir. 1995); Liger, 565 F. Supp. 2d 680. The district court in Bridewell did define the applicable establishment, albeit too 
all three courts simply assumed that as the defendant in the case, the entire team itself — including both its game-day and general business operations - constituted one establishment under the FLSA. ${ }^{164}$

In fact, only one prior court has taken the predicate step of defining the applicable establishment in question in a case applying Section 213(a)(3) to a professional sports team. ${ }^{165}$ In Adams v. Detroit Tigers, several former batboys sued MLB's Detroit Tigers, alleging that the team had failed to pay them in accordance with the FLSA's minimum wage and overtime provisions. ${ }^{166}$ The district court began its analysis by defining the relevant establishment to be only the Tigers' instadium, game-day operations - which lasted for fewer than seven months 167 - rather than the year-round operations of the franchise as a whole. ${ }^{168}$ This finding became largely irrelevant to the analysis, however, as the district court was bound to follow the Sixth Circuit's earlier ruling in Bridewell, holding that professional baseball teams were "a year-round operation" that could not "qualify for an exemption under the seven-month test" set forth in subsection (A). 169 The Adams court did go on to hold that the Tigers fell within Section 213(a)(3)(B)'s receipts provision, though, insofar as the team's average off-season receipts were less than one-third of its average in-season receipts. ${ }^{170}$

narrowly. Bridewell v. Cincinnati Reds, No. C-1-93-203, 1994 WL 866091, at *1 (S.D. Ohio March 24, 1994) (holding that each game played by the Reds was a separate establishment). Indeed, given the applicable regulations' focus on physical places of business, the district court's conclusion that each game played by a baseball team was a separate establishment was clearly erroneous considering that all of those games were housed in the same facility. See 29 C.F.R. \& 779.23 (2011) (generally defining "establishment" as "a "distinct physical place of business").

164 See Jeffery, 64 F.3d at 596; Bridewell, 68 F.3d at 138-39; Liger, 565 F. Supp. 2d at 684 .

165 In addition to the Adams case, discussed infra notes 166-70, the district court in Bridewell reached an erroneous conclusion regarding the establishment at issue in the suit, as discussed above. See supra note 163.

166 Adams v. Detroit Tigers, Inc., 961 F. Supp. 176, 177 (E.D. Mich. 1997) ("Plaintiffs chiefly claim that they were not paid overtime compensation and minimum wages for their work, in violation of state and federal laws.").

$167 \mathrm{Id}$. at 180 ("[I]t is undisputed that Tiger games are not played during the months of November through March, limiting batboys' employment to only seven months of the year.").

168 See id. at 179-80 ("An 'establishment' is a 'distinct physical place of business' in this case, the Tigers' establishment at Tiger Stadium, and not the Tigers' organization as a whole.").

169 Id. at 180.

170 Id. ("[F] or each year from 1992 to 1995, the average of six months of off-season receipts is less than $33^{1 / 3}$ of the average of in-season receipts for the rest of the year."). 
Thus, existing courts applying Section 213(a)(3) to professional sports teams are split, with two courts (Jeffery and Adams) holding that the teams were exempt from the FLSA, while two others (Bridewell and Liger) have held that the year-round nature of sports teams operations as a whole disqualified them from protection under the exemption.

\section{B. The Proper Analysis of Professional Sports Teams Under Section 213(a) (3)}

\section{Identifying the Establishment}

As noted above, courts considering the status of professional sports teams under Section 213(a)(3) have, to date, largely failed to properly define the relevant establishment at issue in the litigation. ${ }^{171}$ This oversight is particularly significant because, when properly defined, professional sports teams may often consist of multiple establishments, some of which may qualify for seasonally exempt status, and others of which will not. ${ }^{172}$ Indeed, most sports teams' operations can generally be divided into two categories: those directly dealing with the team's in-stadium, game-day operations (such as parking, concessions, and grounds keeping), and those relating to its general business operations (e.g., general accounting, marketing, merchandising, and sponsorship solicitation functions). Thus, by correctly identifying the relevant establishment, courts can avoid much of the conceptual difficulty entailed in determining the seasonal duration of a team's operations.

The relevant question under this first step of a Section 213(a)(3) analysis is whether a team uses one establishment or multiple establishments to conduct its diffuse game-day and general business operations. As discussed in Part II.A above, under the applicable regulations, a business unit occupying a "distinct physical place of business" is usually considered a separate establishment for purposes of Section 213(a)(3). ${ }^{173}$ In many cases, both a team's game-day and

\footnotetext{
However, because the plaintiffs did not contest these figures, it is unclear if the team's receipts revenue was calculated correctly. See id. ("Since plaintiffs do not dispute Fisher's calculations, the Tigers have shown that they are an establishment qualifying for an exemption from the minimum wage and overtime requirements of the FLSA."); see also supra Part II.C.2 (discussing \& 213(a)(3)(B)).

171 See supra notes 163-64 and accompanying text.

172 See infra notes $173-87$ and accompanying text.

17329 C.F.R. \& 779.23 (2011).
} 
general business operations will be located in a single facility - its stadium or arena - thereby presumptively rendering the team a single establishment under 29 C.F.R. § 779.23. Should a team house some or all of its business operations in a separate location, however, then those units of the business would usually constitute a separate establishment under this same regulation. ${ }^{174}$

Even in cases where all of a team's employees are housed in a single facility, though, its business and game-day operations may nevertheless properly be considered different establishments under 29 C.F.R. \& 779.305, which delineates separate establishments located on the same premises. As previously noted, ${ }^{175}$ courts applying this regulation consider three factors when deciding whether separate establishments exist within a single facility: physical separation of activities, separation of record- and book-keeping, and interchange of employees. ${ }^{176}$

The DOL applied these three factors in an opinion letter to a professional sports team in 1978, ruling that even though the team's administrative business offices were located within its arena, they nevertheless constituted a separate, non-exempt establishment from the team's game-day operations. ${ }^{177}$ Indeed, a team's business operations will often be housed in a physically separate part of the stadium, with minimal overlap between the team's business and gameday-related employees (the former of which will typically be employed year-round, while the latter generally work on a seasonal basis).178

Moreover, a team's business operations will usually be functionally separate from its game-day operations. ${ }^{179}$ Employees within the team's

174 Professional sports teams would not appear to present the type of "unusual circumstance" that would warrant combining multiple separate physical locations into a single establishment under 29 C.F.R. § 1620.9, since teams generally do not operate at multiple distinct locations with a central administrative unit assigning employees to different, frequently changing work locations. See supra notes 96-99 and accompanying text.

175 See supra note 89 and accompanying text.

176 See Chao v. Double JJ Resort Ranch, 375 F.3d 393, 398-99 (6th Cir. 2004) (reciting standard).

177 Fair Labor Standards Act (Dep't of Labor Oct. 11, 1978) (Opinion Letter), available at 1978 WL 51434, at *1 ("It is also evident that the administrative offices of the $* * *$ comprise a separate establishment on the premises of the Arena.").

178 See, e.g., id. (noting that the team in question did not maintain its administrative offices in a section of the arena in "which the general public has recourse for its amusement or recreation").

179 See, e.g., Liger v. New Orleans Hornets NBA Ltd. P'ship, No. 05-1969, 2006 WL 2850157 , at ${ }^{*} 1$ (E.D. La. Oct. 4, 2006) (characterizing ticket sales employees of the New Orleans Hornets as working "in the 'business enterprise' of the organization"). 
general business establishment primarily conduct non-recreational, traditional business functions such as accounting, contract negotiation, corporate sponsorship solicitation, and general marketing services. 180 Meanwhile the team's game-day establishment operates to provide amusement or recreational services directly to the public. Thus, while the extent to which a team maintains separate records and bookkeeping for its business and game-day operations may vary on a case-by-case basis, it appears that a sports team will often consist of two different establishments under the applicable regulations. ${ }^{181}$

Admittedly, a suit involving a team's ticket sales department will likely present the most challenging scenario under this framework. On the one hand, ticket sales are directly related to the team's provision of game-day recreational services. On the other hand, many ticket sales - season tickets, advanced single game tickets, group tickets - will be sold by the team's general business office, often during the nonplaying season. ${ }^{182}$ Therefore, depending on the facts, a court may properly conclude that a team's advanced ticket sales activities make up part of its general business operations, while walk-up game-day ticket sales at the stadium or arena box office are part of the game-day establishment. 183

180 See, e.g., Front Office Directory, DetroitTigers.COM, http://detroit.tigers.mlb. com/team/front_office.jsp?c_id=det (last visited June 24, 2015) (identifying separate corporate sales, finance, marketing, and ticket sales departments within the organization of MLB's Detroit Tigers).

181 This suggested demarcation mirrors the approach recently adopted by the district court in Hill v. Delaware North Companies Sportservice, Inc., a case involving the applicability of § 213(a)(3) to concessionaires working at Oriole Park at Camden Yards, the home stadium of MLB's Baltimore Orioles. No. 11-cv-00753-WMS-JJM (W.D.N.Y. July 28, 2014). In particular, the Hill court concluded that the Orioles' baseball stadium constituted the relevant establishment for purposes of determining the applicability of the exemption. Id. at 5 ("[T] he relevant establishment (that is, the 'distinct physical place of business') is Oriole Park at Camden Yards, not the Orioles team.").

In addition, the Second Circuit Court of Appeals also correctly focused heavily on the proper characterization of the relevant establishment in its recent decision in Chen v. Major League Baseball Props., Inc., No. 14-1315-cv (2d Cir. Aug. 14, 2015). In particular, the Chen court held that MLB's All-Star week FanFest convention was itself a stand-alone establishment for purposes of applying \& 213(a)(3). Id. at *22 ("[W]e agree with the district court that for purposes of the Section 13(a)(3) exemption, FanFest constitutes a separate establishment.").

182 See, e.g., Bridewell v. Cincinnati Reds, No. C-1-93-203, 1997 WL 1764776, at *3 (S.D. Ohio Mar. 5, 1997) (stating that MLB's Cincinnati Reds receive "a significant portion of its revenue, i.e., income, from season tickets in the off-season").

183 Meanwhile, should the same employee sell tickets in both an advanced and game-day capacity, then they would likely be considered to work for the non-exempt 
Furthermore, in some cases a team's game-day operations may themselves properly be divided into multiple separate establishments. For example, all thirty MLB teams stage a month-and-a-half-long preseason schedule with games held in either Florida or Arizona in February and March. 184 Because these "spring training" games are staged in a "distinct place of business" apart from the teams' normal site of operations, they normally would be considered a separate establishment under 29 C.F.R. \& 779.23.185 Similarly, many NFL teams sell (or provide complimentary) tickets enabling their fans to watch the team's preseason practice sessions. ${ }^{186}$ Since these practices are usually held at a location apart from the team's game-day stadium, ${ }^{187}$ they may also typically constitute a separate establishment.

\section{Determining the Establishment's Amusement or Recreational Status}

Once the applicable establishment has been identified, the next step under Section 213(a)(3) will be to consider whether that establishment is sufficiently amusement or recreational in nature. ${ }^{188}$ In cases where a team's game-day and general business operations are both properly considered part of a single, common establishment, then the court must consider whether the team's "principal activity" — as determined by its majority revenue source - is its amusement-related, game-day operations or its non-exempt, general business activities. 189 In most cases, the general business operations will likely generate a

general business establishment under 29 C.F.R. § 779.311, discussed above. See supra note 84.

184 See Michael J. Mozes \& Ben Glicksman, Adjusting the Stream? Analyzing Major League Baseball's Antitrust Exemption After American Needle, 2 HARV. J. SPORTS \& ENT. L. 265, 267 n.7 (2011) (noting that MLB "operates two spring training leagues, one in Florida and another in Arizona").

18529 C.F.R. § 779.23 (2011). In fact, a MLB team's spring training operations may actually constitute two separate establishments, one for the team's spring training business operations, and the second for its game-day provision of recreational entertainment to the public.

186 See, e.g., Training Camp Schedule, BuffaloBills.COM, http://www.buffalobills. com/team/training-camp/practice-schedule.html (last visited June 6, 2015) (stating that "[t]ickets are needed for [certain] practices").

187 See id. (stating that the Bills' practices are held at St. John Fisher College in Pittsford, NY).

188 See Opinion Letter on FLSA, Sept. 28, 2006, supra note 82, at *2 (explaining that "[t]he second step in applying section 13(a)(3) is to determine whether each establishment qualifies as 'amusement or recreational'").

189 See supra notes 113-20 and accompanying text. 
greater share of the team's revenue, making the entire team a single, non-exempt establishment. This is due to the enormous revenues generated by a team's general business operations, including most notably the team's television broadcast agreements, which are negotiated by the team's business staff and can be worth hundreds of millions of dollars per year. ${ }^{190}$

Meanwhile, in cases where a team's game-day and business activities qualify as separate establishments, the analysis will vary depending on which segment of the team's operations are at issue. Because a sports team's game-day operations provide amusement or recreational services directly to the public, those facets of its business will presumably almost always satisfy this second stage of the analysis. Meanwhile, a team's general business operations would not qualify as an amusement or recreational establishment, as those portions of the enterprise conduct non-recreational business activities. In this regard, the correct analysis will follow Brennan v. Yellowstone Park Lines, in which the Tenth Circuit held that the accounting, marketing, and maintenance offices at Yellowstone National Park were not amusement or recreational establishments. ${ }^{191}$ This phase of the analysis will thus typically end the inquiry in cases dealing with workers in a sports team's business operations, as those portions of the enterprise will not qualify as an amusement or recreational establishment and thus fall outside the Section 213(a)(3) exemption.

\section{Evaluating the Seasonal Nature of the Establishment}

In cases where a team's game-day operations constitute a separate establishment, the final factor a court will have to consider is whether that establishment operates seasonally. 192 Under subsection (A)'s duration test, this inquiry will predominantly focus on the length of the team's playing season. Not only will such an analysis vary from league to league, but it may even differ from franchise to franchise within a

190 See, e.g., Wendy Thurm, Dodgers Could Be Last Team to Strike Gold with Local TV Deal, FANGRAPHS.COM (July 26, 2013), http://www.fangraphs.com/blogs/dodgerscould-be-last-team-to-strike-gold-with-local-tv-deal/ (reporting that some MLB teams earn as much as $\$ 340$ million per year from their local television broadcast agreements).

191 Brennan v. Yellowstone Park Lines, Inc., 478 F.2d 285, 290 (10th Cir. 1973).

192 Opinion Letter on FLSA, Sept. 28, 2006, supra note 82, at *2 (stating that "[t]he final step in applying section 13(a)(3) is to determine whether each [establishment] meets the requirements of section $13(\mathrm{a})(3)(\mathrm{A})$ regarding the duration of [its] operation or section 13(a)(3)(B) regarding [its] receipts"). 
particular league depending on how far each team advances into postseason play, thereby extending the length of its playing season.

For example, the game-day operations for NFL teams will typically qualify as seasonal establishments under subsection (A) due to the relatively short duration of the league's playing season, from September to December. ${ }^{193}$ Even if one were to also factor in the team's preseason games in August - which, unlike the practice sessions discussed above, ${ }^{194}$ are typically held at a team's regular season stadium - the longest a team's season could run would be seven months, assuming the club made it all the way to the Super Bowl in February. ${ }^{195}$ As a result, it appears that NFL teams' game-day employees, such as ticket takers, ushers, concessionaires, and parking attendants, generally will not be entitled to the FLSA's minimum wage and overtime protections.

Similarly, MLB teams' game-day operations will often qualify as seasonal establishments under subsection (A) as well. The MLB regular season typically runs six months, from April through September, ${ }^{196}$ although in some years the season may begin in March and/or extend into early-October. ${ }^{197}$ Meanwhile, ten MLB teams will qualify for the playoffs each year, typically held in October (but

193 See, e.g., Vinnie Iyer, 2014 NFL Schedule Release: Who Will Be Seahawks' Opening Opponent?, SPORTINGNEWS.COM, http://www.sportingnews.com/nfl/story/2014-04-21/ 2014-nfl-schedule-release-regular-season-seahawks-kickoff-opener-broncos-packers-

49ers-patriots-bears-cowboys-redskins (last visited Aug. 3, 2015). The NFL regular season has, on occasion, extended into January. See, e.g., NFL 2011 Regular Season Week 17 Schedule, NFL.COM, http://www.nfl.com/schedules/2011/REG17 (last visited Aug. 13, 2015) (showing the 2011 NFL regular season ending on January 1, 2012).

194 See supra notes 186-87 and accompanying text.

195 See, e.g., David Steele, NFL Preseason Schedule 2014: Seahawks, Broncos Meet Again, SPORTINGNEWS.COM, http://www.sportingnews.com/nfl/story/2014-04-09/nflpreseason-schedule-2014-tv-date-time-giants-bills-regular-season-schedule-seattledenver-super-bowl-rematch (last visited July 26, 2015).

196 For example, the 2013 MLB season began for most teams on April 1, 2013 and ended on September 30, 2013. See Schedule, MLB.COM, http://mlb.mlb.com $/ \mathrm{mlb} /$ schedule/index.jsp?tcid=mm_mlb_schedule\#date=03/31/2013 (last visited June 6, 2015) (showing the start of the regular season); Schedule, MLB.COM, http://mlb.mlb. com/mlb/schedule/index.jsp?tcid=mm_mlb_schedule\#date $=09 / 29 / 2013$ (last visited June 6, 2015) (listing the end of the regular season).

197 See, e.g., Schedule, MLB.COM, http://mlb.mlb.com $/ \mathrm{mlb} / \mathrm{schedule} / \mathrm{index} . j \mathrm{sp}$ ? mode $=14$ r\&tcid $=m m \_m l b \_s c h e d u l e \# d a t e=03 / 31 / 2014$ (last visited June 6, 2015) (revealing that MLB's 2014 regular season began on March 31, 2014); Schedule, MLB.COM, http://mlb.mlb.com/mlb/schedule/index.jsp?tcid=mm_mlb_schedule\#date= 10/01/2012 (last visited June 6, 2015) (showing the end of MLB's 2012 regular season to be October 3rd). 
occasionally creeping into November). 198 Therefore, in most cases, a team's game-day operations will last seven months or less. However, should a team host a regular season game in March, and also continue playing into October, then its season would span eight months, disqualifying it from relying on subsection (A). 199

The exempt status of NBA franchises' game-day operations may also vary depending on whether the team in question qualifies for the playoffs in a particular year. The NBA regular season generally lasts seven months, beginning in late-October and ending in early-April.200 And though NBA teams - like those in the NFL - typically host preseason games in their regular season arenas, the NBA's preseason schedule is generally limited to the month of October, meaning that most teams will still only operate for seven months per year, thus qualifying their game-day operations for seasonal status under subsection (A). ${ }^{201}$ However, should a team advance deep into the NBA playoffs, then its season could extend as many as eight or nine months in a year, in which case its game-day operations would no longer be exempt from the FLSA. ${ }^{202}$

Finally, National Hockey League ("NHL") teams also generally play a seven-month regular season schedule, starting in early-October and

198 See 2010 MLB Postseason Schedule, MLB.com, http://mlb.mlb.com/mlb/schedule/ ps.jsp?y=10 (last visited June 6, 2015) (noting that the 2010 World Series ended on November lst).

199 Moreover, some MLB franchises may also potentially be disqualified from reliance on subsection (A) by virtue of the fact that they offer their fans the opportunity to tour the team's stadium on a year-round basis, thus extending the duration of a team's provision of in-stadium, amusement or recreational services beyond the seven-month threshold required under subsection (A). See, e.g., Stadium Tours, GIANTS.COM, http://sanfrancisco.giants.mlb.com/sf/ballpark/information/index. jsp? content=tours (last visited Sept. 29, 2015) (noting that the team offers fans tours of its stadium year-round); Stadium Tours, YANKEES.COM, http://newyork.yankees.mlb. com/nyy/ballpark/stadium_tours.jsp (last visited June 6, 2015); see also U.S. Dep't of Labor, Wage \& Hour Div., Miami Marlins Case ID 1703046, Narrative Report, at 3 (Feb. 11, 2014) (concluding that MLB's Miami Marlins were not exempt under Section 213(a)(3)(A) in part because they offered year-round tours of their stadium).

200 See Dan Devine, 2013-14 NBA Schedule Released, Yaноо.сом (Aug. 6, 2013), http://sports.yahoo.com/blogs/nba-ball-dont-lie/2013-14-nba-schedule-released-30teams-schedules-224020884.html (noting that the NBA's 2013-14 season was scheduled to begin on Oct. 29, 2013).

201 See, e.g., NBA's 116-game Preseason Tips Off in Istanbul on Oct. 5, NBA.COM, http://www.nba.com/2013/news/08/15/nba-preseason-schedule-release-2013/ (last visited June 6, 2015) (stating that the NBA 2013 preseason begins October 5th).

202 See NBA Playoffs 2014 - The Finals Schedule, NBA.com (June 1, 2014, 12:41 AM), http://www.nba.com/2014/news/06/01/nba-finals-schedule/ (last visited June 6, 2015) (reporting that the 2014 NBA Finals would potentially last until June 20th). 
ending in early-April. ${ }^{203}$ Unlike their NBA counterparts, however, the NHL's preseason schedule begins each year in September, with games generally held in each team's regular season home arena, ${ }^{204}$ meaning that NHL teams will usually operate for at least eight months per year (and maybe more depending on how far they advance in the playoffs). ${ }^{205}$ Consequently, when viewed properly, NHL teams will rarely qualify as seasonal establishments under subsection (A) because the combined length of their pre- and regular season schedules will almost invariably span more than seven months in a given year.

Should a professional sports team's game-day operations fail to satisfy subsection (A), then the team will have to try to establish its seasonal status under subsection (B)'s receipts test. As discussed above, a team's advanced ticket sales will often be a part of its business establishment, meaning that the team's game-day revenues will be derived primarily from walk-up ticket, parking, food, and in-stadium merchandise sales. ${ }^{206}$ Considering the relatively short duration of the playing seasons in the four major sports, ${ }^{207}$ most teams will therefore likely satisfy the receipts test under subsection (B) with respect to their game-day operations. Indeed, the average in-stadium receipts generated by a team during its lowest six months will usually be less than one-third its average receipts for its six highest months, since the team's game-day operations will only generate de minimis revenue during the off-season. The DOL's San Francisco field office, for example, recently closed an investigation into the cheerleader pay practices of the NFL's Oakland Raiders, concluding that the team was exempt from the FLSA under subsection (B).208 Thus, although the

203 See, e.g., NHL Announces 2013-14 Season Schedule, NHL.COM (July 19, 2013, 1:05 PM), http://www.nhl.com/ice/news.htm?id=678238 (reporting that the 2013-14 "NHL regular season opens on Tuesday, Oct., 1" and "concludes on Sunday, April 13").

204 See id. (listing important dates in the 2013-14 NHL preseason and regular season).

205 See 2013-14 NHL Preseason Begins Saturday, Sept. 14, NHL.Com (Aug. 8, 2013, 10:00 AM), http://www.nhl.com/ice/news.htm?id=679789 (stating that the NHL's 2013 preseason schedule would begin on September 14th).

206 See supra note 183 and accompanying text.

207 See supra notes 193-205 and accompanying text.

208 U.S. Dep't of Labor, Wage \& Hour Div., Oakland Raiders Case ID 1717965, FLSA Narrative Report, at 3 (Feb. 26, 2014) ("The employer was able to provide documentation that disclosed that during each preceding calendar year of the time covered during the investigative period, its average receipts for any six months of such year were not more than 33-1/3 per centum of its average receipts for the other six months of such year."). Unfortunately, the field office's opinion did not include any supporting data, nor specify whether it relied on the cash method of accounting. See generally id. 
applicability of subsection (B) to a sport team's game-day operations will require a heavily fact-dependent, case-by-case inquiry, it appears that most teams' game-day operations will likely qualify as exempt establishments under the provision.

\section{Implications for Pending FLSA Cases Against Professional Sports Teams}

Professional sports teams in three of the four major U.S. professional sports leagues have been sued recently for alleged minimum wage or overtime violations. As noted above, ${ }^{209}$ seven such lawsuits have been filed by cheerleaders against five different NFL teams, alleging that the franchises have effectively paid their cheerleaders as little as $\$ 2.85$ per hour once all of the cheerleaders' required duties - practices, gameday performances, and other public appearances - are factored in. ${ }^{210}$ These pay practices are particularly troubling considering that NFL cheerleading squads have been estimated to generate as much as $\$ 1$ million per year in revenue for their team, ${ }^{211}$ with teams sometimes charging upwards of $\$ 300$ per hour to have their cheerleaders appear at private events. ${ }^{212}$ Meanwhile, some of these same NFL franchises reportedly pay the male employees who don mascot costumes anywhere from $\$ 35,000$ to $\$ 65,000$ per season. ${ }^{213}$ Although several of the pending cheerleader lawsuits assert only state law claims, ${ }^{214}$ others allege violations of the FLSA, 215 thus implicating the status of NFL teams under Section 213(a)(3). Moreover, considering that cheerleaders and dance squad members in both the NBA and NHL

\footnotetext{
209 See supra notes 1-9 and accompanying text.

210 See Brenneman Complaint, supra note 1, at 2. The five teams are the Buffalo Bills, Cincinnati Bengals, New York Jets, Oakland Raiders, and Tampa Bay Buccaneers. See supra notes 6-9 and accompanying text.

211 Rob Wherry, Pom-Poms and Profits, FORBES (Sept. 15, 2013), http://www.forbes. com/free_forbes/2003/0915/084.html ("[O]n average the 25 teams that have cheerleaders probably gross just over $\$ 1$ million a season.").

212 See Brenneman Complaint, supra note 1, at 7 ("[T] he Cincinnati Bengals charge approximately the same rate for their cheerleaders to appear at events as other NFL organizations, or around $\$ 300$ an hour.").

213 Grant Cohn, NFL Cheerleading a Rah Deal, Press Democrat (June 24, 2014), http://49ers.pressdemocrat.com/nfl-cheerleading-rah-deal/ ("NFL mascots earn between $\$ 35,000$ and $\$ 65,000$ a season.").

214 See, e.g., Sanchez Complaint, supra note 6; Caitlin Y. Complaint, supra note 6; Class Action Complaint, Lacy T. v. Oakland Raiders, No. RG14710815 (Cal. Super. Ct. Jan. 22, 2014); Krystal C. Complaint, supra note 8; Jaclyn S. Complaint, supra note 9.

215 Collective Action Complaint, Pierre-Val v. Buccaneers Ltd. P'ship, No. 14-cv1182-T-33EAJ (M.D. Fla. May 19, 2014); Brenneman Complaint, supra note 1, at 13-15.
} 
may also be subjected to similar pay practices, teams in those leagues could soon be facing their own lawsuits under the FLSA. ${ }^{216}$

Meanwhile, all thirty MLB teams are currently defending themselves in two class action lawsuits asserting that they have violated the FLSA's minimum wage and overtime provisions. ${ }^{217}$ In Senne v. Office of the Commissioner of Baseball218 and Marti v. Office of the Commissioner of Baseball,219 former minor league baseball players allege that they earned as little as $\$ 3,000$ to $\$ 7,500$ per year220 despite being required to spend well over forty hours per week at the stadium before, during, and after their six or seven scheduled games per week. ${ }^{221}$ These duties are in addition to their mandatory, but unpaid, pre- and postseason training obligations. 222 The MLB defendants have responded to these allegations by asserting, inter alia, that they are exempt from the FLSA under Section 213(a)(3).223

216 See Julia Lurie, The Freezing, Hungry Lives of NHL "Ice Girls," MOTHER JONES (June 11, 2014), http://www.motherjones.com/politics/2014/06/philadelphia-flyersice-girls-los-angeles-kings-new-york-rangers-stanley-cup-finals (reporting that NHL ice dancers are subject to treatment similar to NFL cheerleaders); Rachel L. Swarns, Dancing for the Knicks Is a Coveted Opportunity, but the Salary Is a Secret, N.Y. TIMES (June 15, 2014), http://www.nytimes.com/2014/06/16/nyregion/knicks-are-mumabout-salaries-of-the-teams-dancers.html?_r=0 (stating that the salaries paid to cheerleaders for the NBA's New York Knicks are secret).

217 In addition to these two minor league wage suits filed under the FLSA, a class action antitrust lawsuit was filed on behalf of minor league baseball players in December 2014. Class Action Complaint, Miranda v. Office of the Comm'r of Baseball, No. 14-cv-05349 (N.D. Cal. Dec. 5, 2014). This suit faces long odds of success, though, in light of MLB's exemption from antitrust law. See, e.g., Nathaniel Grow, Defining the "Business of Baseball": A Proposed Framework for Determining the Scope of Professional Baseball's Antitrust Exemption, 44 UC DAvis L. REv. 557, 565-75 (2010) (discussing the origins and development of baseball's antitrust exemption).

218 No. 14-cv-00608-JCS (N.D. Cal. Feb. 7, 2014).

219 No. 3:14-cv-03289-RS (N.D. Cal. July 21, 2014).

220 See Second Amended Complaint at 36, Senne v. Office of the Comm'r of Baseball, No. 14-cv-00608-JCS (N.D. Cal. May 16, 2014) ("Plaintiffs believe that most minor leaguers earn less than $\$ 7,500$ per calendar year. Some earn $\$ 3,000$ or less.").

221 See id. at 39 ("In a seven-day workweek — which is typical — the minor leaguer consequently works well in excess of forty hours at the stadium.").

222 See id. at 33 (stating that "minor leaguers work without earning a paycheck" during the required spring training practice sessions); id. at 36-37 ("At the end of the championship season, around 30-45 minor leaguers per MLB Franchise are also selected to participate in an instructional league to further hone their skills... without pay."); id. at 38 ("[T]he Defendants therefore require players to perform extensive training and conditioning during the winter off-season.").

223 See Answer to the Second Amended Complaint at 72, Senne v. Office of the Comm'r of Baseball, No. 14-cv-00608-JCS ("Plaintiffs' claims and those of certain putative collective members under the FLSA are barred by the exemptions afforded 
In addition to these pending class action lawsuits, MLB teams are also facing a series of investigations into their pay practices by the DOL.224 A September 2013 memorandum to all thirty MLB teams reports that the DOL believes that FLSA violations "are endemic to [the baseball] industry," 225 with three MLB teams - the Miami Marlins, Oakland Athletics, and San Francisco Giants - having already reportedly reached settlements with the DOL in which the teams agreed to pay hundreds of thousands of dollars in back wages to various groups of team employees. 226

Finally, both MLB itself and the NBA's Los Angeles Clippers have faced recent lawsuits brought by unpaid volunteers or interns, litigation that similarly alleges a failure to abide by the FLSA's minimum wage and overtime provisions.227 Indeed, given their "glamour" industry status, professional sports teams may often be able to rely on unpaid volunteers and interns, exposing the teams to FLSA liability if a court determines that these workers are, in fact, employees eligible for protection under the FLSA. Fear of this sort of lawsuit reportedly motivated the NFL to discontinue its use of some unpaid volunteer positions at the 2014 Super Bowl.228

to . . seasonal, amusement or recreational establishments.").

224 See Myron Levin \& Stuart Silverstein, Investigation of Pay Practices Targets Two More Major League Teams, the Orioles and A's, FAIRWARNING (May 22, 2014), http:// www.fairwarning.org/2014/05/investigation-pay-practices-major-league-baseballexpands-two-teams/ (stating that four MLB "clubs that have come under scrutiny for possible violations of U.S. wage standards").

225 Memorandum from Robert D. Manfred, Jr. \& Dan Halem to All Presidents and Club Counsel (Sept. 12, 2013), available at http://www.fairwarning.org/wp-content/ uploads/2013/10/Sept.-12memo.pdf.

226 See Josh Eidelson, Oakland A's Will Pay Back Wages to Interns and Clubhouse Workers, BLOOMBERG BuSINESS (Sept. 5, 2014), http://www.bloomberg.com/bw/articles/ 2014-09-05/oakland-as-will-pay-back-wages-to-interns-and-clubhouse-workers (reporting that the Oakland Athletics agreed to pay "86 current or former" employees "a total of $\$ 266,358$ " in back pay); Levin \& Silverstein, supra note 224 (reporting that the Miami Marlins agreed to pay " $\$ 288,290$ in back wages and damages to 39 team employees, including clubhouse and office staff," while the San Francisco Giants will pay "\$220,793 in back wages and damages to 78 employees").

227 Class Action Complaint at 19-20, Chen v. Major League Baseball, 6 F. Supp. 3d 449 (2d Cir. Aug. 7, 2013) (No. 13-CV-5494) (alleging that MLB violated the FLSA by failing to pay volunteers at the annual FanFest exhibition held in conjunction with the All-Star Game); Complaint at 2, Cooper v. LAC Basketball Club, Inc., No. 2:14-cv04445 (C.D. Cal. June 10, 2014) (pursuing relief on behalf of a class of former unpaid interns for the Los Angeles Clippers).

228 See Tom Pedulla, The Price for Super Bowl Volunteers, N.Y. TimEs (Jan. 28, 2014), http://www.nytimes.com/2014/01/29/sports/football/use-of-volunteers-questioned-asnfl-revenue-soars.html (reporting that "[t]he N.F.L. opted to hire temporary paid workers for positions in which volunteers had typically been used" in "apparent 
The pending lawsuits against the NFL, MLB, and NBA are likely to have mixed success should courts apply the analysis proposed in this article. For example, the NFL teams appear to have a strong chance of prevailing in the pending lawsuits brought by their cheerleaders, since the cheerleaders will usually be affiliated with a team's game-day operations. The NFL franchises will therefore be able to assert exempt status in the cases as a seasonal amusement or recreational establishment under Section 213(a)(3)(A), given the relatively short duration of the NFL playing season. 229

In response, the cheerleaders' best argument may be to assert that their squads constitute a separate establishment apart from their team's general game-day operations. ${ }^{230}$ For instance, unlike most of a team's game-day staff, cheerleaders are required to attend many practice sessions and make a number of other non-game-day appearances. 231 Thus, the majority of the cheerleaders' duties are arguably functionally separate from the rest of the team's game-day operations. Should the required practice sessions and promotional appearances be held at physical locations that are separate from the team's stadium, and should the team maintain separate records and bookkeeping for its cheerleader squad, then the cheerleaders will have an even stronger claim for separate establishment status. If a court ultimately concludes that the cheerleader squads do in fact constitute a separate establishment, then their operations may not satisfy subsection (A)'s seasonal duration requirement, as the squads typically operate for eight or nine months per year (from late-May to December or January).232 Even then, though, the cheerleading establishment may itself satisfy subsection (B)'s revenue test, depending upon when any cheerleader-related revenues are received.

Similarly, the pending class action lawsuits brought on behalf of minor league baseball players against MLB may also be barred by the Section 213(a)(3) exemption. Because most minor league players are employed directly by a MLB franchise - rather than their minor league team - MLB teams can plausibly argue that each of their minor league

\footnotetext{
response to a class-action suit brought ... against Major League Baseball").

229 See supra notes 192-95 and accompanying text.

230 See supra note 89 and accompanying text.

231 See, e.g., Brenneman Complaint, supra note 1, at 2 (stating that cheerleaders for the Cincinnati Bengals "are required to attend at least 6-8 hours of mandatory practices every week from late May through December" and "are required to appear at no fewer than 10 "charity' functions a season").

232 See id. at 2 (noting that the Cincinnati Bengals' cheerleaders practice "every week from late May through December").
} 
affiliate teams constitutes a separate establishment under the FLSA. Indeed, because each minor league franchise operates in a "distinct physical place of business" apart from its MLB parent club, ${ }^{233}$ these teams would appear to satisfy the standard for physically separate establishments set forth in 29 C.F.R. \& 779.23.234 The minor league players could argue in response that their case presents one of the "unusual circumstances" in which physically separate operations constitute a single establishment under 29 C.F.R. \& 1620.9, since the MLB franchises assign their minor league players to a variety of geographically diverse locations. ${ }^{235}$ However, even if a court were to determine that the minor league teams are not separate establishments, and do in fact constitute part of each MLB franchise's game-day operations as a whole, as noted above, most MLB teams' game-day operations will presumably qualify for seasonally exempt status under Section 213(a)(3)(A) or (B).236 Thus, it appears that the minor league players' lawsuits will also be excluded from the FLSA's coverage.

Finally, though the recent class action filed by an unpaid intern of the Los Angeles Clippers was voluntarily dismissed without prejudice by the plaintiff, 237 if it or a similar case is refiled, the court will have to determine whether the interns were employed in the Clippers' business or game-day operations. Indeed, because the lead plaintiff reportedly "worked in the NBA team's fan relations department, where he made calls to season-ticket holders and helped organize basketball clinics," it is unclear whether he was employed by an amusement or recreational establishment. ${ }^{238}$ If the court concludes that he worked solely for the team's non-amusement business operations - or simultaneously in both the game-day and general business establishments - then Section 213(a)(3) would not apply.239 However, should the court determine that the intern was employed

\footnotetext{
233 See, e.g., Grow, supra note 217, at 610-11 (explaining that "each MLB franchise maintains close contractual relationships with five or six different minor league teams" and "assign[s] players to each of their minor league teams").

23429 C.F.R. \& 779.23 (1999).

235 See supra notes $94-99$ and accompanying text.

236 See supra notes 196-98, 206-07 and accompanying text.

237 Notice of Voluntary Dismissal, Cooper v. LAC Basketball Club, Inc., No. 2:14cv-04445 (June 18, 2014) (No. 12).

238 Former Clippers Intern Sues Sterlings, Team, NBA.COM (June 11, 2014), http://www.nba.com/2014/news/06/11/clippers-intern-lawsuit.ap/.

239 As noted above, employees simultaneously working for both exempt and nonexempt establishments within a single enterprise are covered by the FLSA under 29 C.F.R. \& 779.311. See supra note 84.
} 
solely within the team's game-day operations, then the team would likely be exempt under subsection (B)'s receipts test. ${ }^{240}$

\section{IMPLiCATIONS FOR PUBlic POLICY AND PROPOSALS FOR REFORM}

As this article has shown, the case law applying Section 213(a)(3) is confused and contradictory, particularly in cases brought against professional sports teams. This article has suggested a simple new framework for analyzing defendants' entitlement to the exemption. However, even if all courts were to apply the exemption as recommended here, Section 213(a)(3) would still raise questions as a matter of policy. This part explores the public policy implications of the exemption before making various proposals for reform.

\section{A. Public Policy Implications}

As an initial matter, Section 213(a)(3)'s seasonality provisions give rise to significant administrative difficulties. In industries with variable season lengths - a professional sports team that may or may not advance to post-season play, for instance - the exemption's application could change from year to year. ${ }^{241}$ This is problematic for employers, whose budgeting for wages would have to change on an annual basis, sometimes dramatically. It also presents difficulties for workers, who would be unable to rely on a consistent annual income. ${ }^{242}$ And for the DOL, which is charged with enforcing the FLSA, monitoring and enforcement become complicated when an employer's exempt status potentially changes from year to year.

Moreover, even if courts employed a proper Section 213(a)(3) analysis, the results in some cases would likely be troubling from a public policy perspective. As Part III.C explained, the pending FLSA cases brought by NFL cheerleaders and minor league baseball players will likely fail as a result of Section 213(a)(3). Assuming that the exemption is the only reason for these claims' failure - rather than a lack of proof establishing minimum wage or overtime violations, for instance - then the law would be permitting employers worth hundreds of millions or even billions of dollars to evade the basic obligation to pay the minimum wage (a mere $\$ 7.25$ per hour) and time-

\footnotetext{
240 See supra notes 206-08 and accompanying text.

241 See supra note 202 and accompanying text.

242 If the exemption does not apply, and employers must pay the minimum wage, then they owe workers $\$ 7.25$ per hour. If the exemption applies, then employers like the Ben-Gals cheerleading squad could revert to their current practice of paying only $\$ 2.85$ per hour, over sixty percent less. See supra notes $1-5$, and accompanying text.
} 
and-a-half overtime. One can hear echoes of the 1966 Senate debate over whether resort hotels would be exempt from the FLSA, in which a senator asked, incredulously, whether "a hotel that is affluent enough to charge a patron $\$ 60$ a day cannot pay a worker $\$ 50$ a week?"243

The exemption of professional sports teams under Section 213(a)(3) is also troubling given powerful groups' historical use of FLSA exemptions to remove legal protections from workers who are already economically and politically vulnerable. ${ }^{244}$ Though workers employed by professional sports teams may seem to lead glamorous lives, many in fact work under exploitative conditions, with little power and voice. Apart from their low pay, some NFL cheerleaders have been subjected to extremely humiliating working conditions, including being instructed on tampon usage and having to pass a body-fat "jiggle test" to ensure their fitness to cheer. ${ }^{245}$ Meanwhile, Buffalo Bills' cheerleaders were instructed, "Do not be overly opinionated about anything. Do not complain about anything[.]"246 Cheerleaders are encouraged not to voice complaints about wages and working conditions, with reminders that "[t]here are more aspiring pros than there are slots on the sideline, so if one cheerleader slips up, there are hundreds of hopefuls waiting to take her place."247 Likewise, many minor league baseball players enter the industry right after high school or before finishing college, while many others are recent immigrants with limited English skills and little familiarity with the United States. ${ }^{248}$ In addition, neither professional cheerleaders nor minor

243112 Cong. ReC. 20,791 (Aug. 26, 1966) (statement of Sen. Pastore).

244 See supra notes 31-35 and accompanying text.

245 See supra note 10.

246 Billy Haisley, Insane Handbook: Bills Cheerleaders Are Told How to Wash Their Vaginas, DEADSPIN (Apr. 24, 2014), http://deadspin.com/how-to-use-a-tampon-andother-guidelines-for-bills-che-1567047406.

247 Amanda Hess, Just Cheer, Baby, ESPN The Magazine (Apr. 2, 2014), http:// espn.go.com/espn/feature/story/_/id/10702976/just-cheer-baby-lacy-t-sues-oaklandraiders ("The strong camaraderie among professional cheerleaders was a selling point for recruiting dancers, but it was also a strategy for keeping the women in line. Cheerleaders were periodically reminded that hundreds of bright young women would kill to take their slot in the sisterhood.").

248 See Tony Dokoupil, Does Major League Baseball Exploit Latino Players?, NBCNEws (Oct. 21, 2014), http://www.nbcnews.com/news/latino/does-major-leaguebaseball-exploit-latino-players-n228316 (noting that more than forty percent of minor league players are Latino); Clint Longenecker, Senior Discount Goes to Extremes in 2014 Draft, BASEBALl AMERICA (June 8, 2014), http://www.baseballamerica.com/ draft/senior-savings-bonanza-the-2014-draft-top-10-rounds/ (noting that from "20082011, an average of 30 seniors were drafted in the top 10 rounds" of the MLB draft, less than 10 percent of draft picks). 
league baseball players are unionized, meaning they lack a collective voice with which to negotiate with their employers.

The power imbalance between these front-line workers and their well-financed, politically influential employers is stark. For example, the professional baseball lobby is particularly, and notoriously, strong: between MLB and the minor leagues, there are almost two hundred teams spread across forty-two states. ${ }^{249}$ As Congressman Emanuel Celler once commented, "I have never known, in my 35 years of experience, of as great a lobby that descended upon the House than the organized baseball lobby... They came upon Washington like locusts." 250 Indeed, representatives for minor league baseball have discussed petitioning Congress to exempt minor league baseball players explicitly from the FLSA. ${ }^{251}$

Finally, the foregoing analysis has public policy repercussions beyond the FLSA, implicating the tax subsidies that municipalities frequently hand out to professional sports teams. Cities have routinely given generous taxpayer subsidies to the sports industry over the last forty years, most often in the form of new stadiums or arenas constructed at public expense. ${ }^{252}$ From 1970 to 1999, for instance, government subsidies for new professional sports facilities totaled an estimated $\$ 10.4$ billion, with an additional $\$ 1.4$ billion spent to refurbish existing stadiums. ${ }^{253}$ This trend has accelerated in the 2000s, with the NFL alone receiving nearly $\$ 2.4$ billion in public stadium subsidies since 2001.254 Across the four major leagues, these publicly

249 See Teams by Geographic Location, MiLB.COM, http://www.milb.com/milb/info/ geographical.jsp (last visited June 6, 2015) (reporting that around 160 minor league teams exist in the United States); Team-by-Team Information, MLB.COM, http://mlb. mlb.com/team/index.jsp (last visited June 6, 2015) (listing all 30 MLB teams).

250 Roger L. Abrams, Legal Bases: Baseball and the LaW 61 (1998).

251 See Josh Leventhal, MiLB Opposes Players, Supports MLB in Lawsuit, BASEBALL AMERICA (Dec. 11, 2014), http://www.baseballamerica.com/minors/milb-opposesplayers-backs-mlb-lawsuit/ ("[Minor league baseball's vice president] announced that beginning next year, he will petition Congress to add minor league baseball players to the list of 35 occupations not required to receive minimum wage or overtime pay as dictated in the [FLSA].").

252 For instance, sixty-five percent of arenas and eighty-seven percent of stadiums housing teams in the four major U.S. professional sports leagues were publicly owned as of the 1990s. Gerald W. Scully, The Market Structure of Sports 24 (1995) (noting same).

253 See David Haddock, Tonja Jacobi \& Matthew Sag, League Structure \& Stadium Rent-Seeking - the Role of Antitrust Revisited, 65 FLA. L. REV. 1, 7 (2013); see also Nathaniel Grow, Regulating Professional Sports Leagues, 72 WASH. \& LEE L. REV. 573, 609-10 (2015) (discussing the level of public subsidization of sports stadiums).

254 See Haddock et al., supra note 253, at 7. 
funded facilities have been estimated to cost their host communities as much as $\$ 500$ million per year. 255

Cities have been willing to dole out these subsidies in order to obtain the perceived economic benefits that many believe sports teams provide to their home communities. ${ }^{256}$ The public often accepts that building a new stadium will not only spur construction-related job creation in the short-term, but also lead to economic growth in and around the new facility in the long-term. ${ }^{257}$ In reality, however, economists have almost uniformly concluded that new sports stadiums have no measurable, positive impact on a city's economy, ${ }^{258}$ as any increased spending in and around a new stadium or arena is usually offset by a reduction in economic activity in other areas of the local economy.259

255 See Thomas A. Piraino, Jr., The Antitrust Rationale for the Expansion of Professional Sports Leagues, 57 OHIO ST. L.J. 1677, 1701 (1996) ("[S]ubsidies for professional sports teams currently drain $\$ 500$ million annually from state and local governments."). Moreover, because many of these projects are financed using federally tax-exempt bonds, U.S. taxpayers effectively subsidize local communities' stadium construction efforts, costing the federal treasury as much as $\$ 120$ million over the course of thirty years for just a single $\$ 300$ million stadium. See PAUL WeILER, LeVeling the Playing Field: How the LaW Can MaKe Sports Better for Fans 264 (2000); Haddock et al., supra note 253, at 11 (discussing the use of federally taxexempt municipal bonds to construct sports stadiums).

256 See Pamela Edwards, Note, How Much Does That \$8.00 Yankee Ticket Really Cost? An Analysis of Local Governments' Expenditure of Public Funds to Maintain, Improve or Acquire an Athletic Stadium for the Use of Professional Sports Teams, 18 FORDHAM URB. L.J. 695, 695 (1991) (explaining that "[m]unicipalities seek the economic and cultural benefits professional sports franchises can bring"); $c f$. Thomas A. Piraino, Jr., A Proposal for the Antitrust Regulation of Professional Sports, 79 B.U. L. REV. 889, 913 (1999) ("Local governments are willing to invest substantial sums to attract teams, as they are desperate to obtain the status of a "major league city."').

257 See David Mark, Comment, Taking One for the Team: The Persistent Abuse of Eminent Domain in Sports Stadium Construction, 5 FLA. INT'L U. L. REV. 781, 801 (2010) ("The people footing the bill for these new stadiums, the individual taxpayers, are promised that the stadiums and teams coming to play in them will bring thousands of new jobs, an increase in tax revenues and income for their city, and an overall feeling of greater civic pride and image that is associated with living in the same city as a professional sports franchise.").

258 See James Quirk \& Rodney Fort, Hard Ball: The Abuse of Power in Pro Team SPORTS 154 (1999) ("In independent studies of the impact of stadiums, there are almost no instances in which stadiums were shown to lead to a measurable increase in the economic well-being of a city."); Haddock et al., supra note 253, at 12-14 (reviewing the relevant economic literature). See generally John L. Crompton, Economic Impact Analysis of Sports Facilities and Events: Eleven Sources of Misapplication, 9 J. SPORT MGMT. 14 (1995) (discussing misuse of economic impact studies to justify public subsidization of playing facilities).

259 See Garrett Johnson, The Economic Impact of New Stadiums and Arenas on Cities, 
These purported economic benefits are further undercut by the fact that the beneficiary teams may not even be required to pay their employees in accordance with minimum wage and overtime laws. Indeed, as discussed above, professional sports franchises will often be exempt from the FLSA's minimum wage and overtime provisions with respect to their game-day operations. ${ }^{260}$ Thus, while the public subsidization of the professional sports industry is generally objectionable as a policy matter, it is particularly unwarranted in cases where the beneficiary team's game-day employees - including ticket takers, ushers, concessionaires, and parking attendants - may not even receive the FLSA's basic guarantee of a minimum hourly wage and overtime pay.

\section{B. Reform Proposals}

In light of the foregoing analyses, this article presents two sets of proposals to address the problems with Section 213(a)(3). The first is a set of incremental changes to the exemption's scope; the second is a set of sweeping reforms to all of the FLSA's exemptions, Section 213(a)(3) included.

On the incremental front, the exemption might be narrowed in three ways that would align it more closely with its original purpose, as gleaned from its legislative history: the protection of economically precarious establishments whose operating seasons are constrained by external factors such as the weather, and as a result must require long hours from their workforce. ${ }^{261}$

First, the minimum wage exemption could be removed from Section 213(a)(3), leaving only the overtime exemption. Indeed, due to their relatively short operating seasons, some truly seasonal businesses may need to require their employees to work a substantial number of hours per week during a handful of months each year. Requiring the payment of time-and-a-half overtime could impose a real hardship on the most economically fragile of these employers, arguably justifying an overtime exemption in some cases. The policy rationale for these same employers to forgo paying the minimum wage, however, is much less clear.

2011 DEN. U. SPORTS \& ENT. L.J. 1, 14-15 ("Studies prove that spending money on sports events is usually offset by reductions in spending in other areas of entertainment by consumers."). This phenomenon is known as a "substitution effect." See id. at 15.

260 See supra Part III.B.

261 See supra note 64 and accompanying text. 
A similar proposal was considered and - unfortunately - rejected by Congress in $1965,{ }^{262}$ as part of the failed set of FLSA amendments discussed above. ${ }^{263}$ These amendments were ultimately rejected due in no small part to the belief that seasonal amusement or recreational establishments at the time frequently employed student workers, employees that were thought to be able to afford to earn a lower wage due to their dependent status. ${ }^{264}$ This same justification in support of Section 213(a)(3) no longer applies today. Recent data from the U.S. Bureau of Labor Statistics show that the median age of workers employed in the "arts, entertainment, and recreation" industries - the category that aligns most closely with the establishments covered by Section 213(a)(3) - was 38.1 years in 2013.265 Thus, unlike the student workers cited by the opponents of the 1965 FLSA amendments, who could arguably afford sub-minimum wages because their earnings were merely supplemental, today's amusement and recreational workers are often adults who rely on their wages to support both themselves and their families. ${ }^{266}$

A second incremental change to Section 213(a)(3) would be for Congress to add a revenue cap above which the exemption would not

262 H.R. ReP. No. 89-871, at 10 (1965) (describing a bill that "[r]epeals the minimum wage and overtime exemptions for such establishments [hotel, restaurant, motion picture, and recreational establishments; hospitals and related institutions] (except that seasonal resorts and seasonal recreational and amusement establishments maintain overtime exemptions")).

263 See supra notes 68-70 and accompanying text.

264 See supra notes 67-70 (discussing legislative history regarding student workers).

265 U.S. Dep't of Labor, Bureau of Labor Statistics, Employed Persons by Detailed Industry and Age, 2013 Annual Averages (last modified Apr. 25, 2014), available at http://www.bls.gov/cps/industry_age.htm.

266 Moreover, recent economic research does not support the oft-cited proposition that an increase in, or expansion of, the minimum wage will necessarily result in job loss. See Daron Acemoglu et al., Time to Raise the Minimum Wage, ECON. POLICY InST. (July 23, 2012), available at http://www.epi.org/publication/raise-minimum-wage/ ("In recent years there have been important developments in the academic literature on the effect of increases in the minimum wage on employment, with the weight of evidence now showing that increases in the minimum wage have had little or no negative effect on the employment of minimum wage workers, even during times of weakness in the labor market."). But see David Neumark \& William Wascher, Minimum Wages and Employment: A Review of Evidence from the New Minimum Wage Research, at i (Nat'l Bureau of Econ. Research, Working Paper No. 12663), available at http://www.nber.org/papers/w12663.pdf ("Our review indicates that there is a wide range of existing estimates and, accordingly, a lack of consensus about the overall effects on low-wage employment of an increase in the minimum wage. However, the oft-stated assertion that recent research fails to support the traditional view that the minimum wage reduces the employment of low-wage workers is clearly incorrect."). 
apply. Here, the amendment could mimic other capped FLSA exemptions such as 29 U.S.C. \& 213(g), which exempts only agricultural employers with revenues below $\$ 10$ million from the minimum wage requirement. ${ }^{267}$ Section $213(\mathrm{~g})$ was enacted as part of a package of FLSA amendments in 1974,268 which expanded the FLSA by bringing farm workers within the statute's coverage for the first time, but in such a way that affected only the very largest agricultural employers. Even the politically formidable farming industry - which has been called "the world's most selfish lobby" 269 - could seemingly accept the application of the FLSA to its largest, richest employers. ${ }^{270}$ Likewise, Section 213(a)(3) could also be capped at $\$ 10$ million in revenues, ensuring that wealthy professional sports franchises, who can plead no economic excuse, would be forced to pay the minimum wage and overtime to their front-line employees.

A third incremental change would be to exclude teams in the four major U.S. professional sports leagues from Section 213(a)(3) without regard to their revenue. One way that such a step could be accomplished would be to state that no entity covered by the Sports

26729 U.S.C. \& 213(g) (2012) ("The [minimum wage] exemption ... shall not apply with respect to any employee employed by an establishment (1) which controls, is controlled by, or is under common control with, another establishment the activities of which are not related for a common business purpose to, but materially support the activities of the establishment employing such employee; and (2) whose annual gross volume of sales made or business done, when combined with the annual gross volume of sales made or business done by each establishment which controls, is controlled by, or is under common control with, the establishment employing such employee, exceeds $\$ 10,000,000$ (exclusive of excise taxes at the retail level which are separately stated)."). A similar cap applied to the exemptions to the minimum wage and overtime requirements for retail and service workers in early versions of the FLSA: employers with more than $\$ 1$ million in revenues received no relief under the exemption. Fair Labor Standards Act Amendments of 1961, Pub. L. No. 87-30, 75 Stat. 65 (1961) (extending FLSA coverage to retail and service employers with annual revenues over $\$ 1$ million).

268 See Patrick M. Anderson, The Agricultural Employee Exemption from the Fair Labor Standards Act of 1938, 12 HAMLINE L. REV. 649, 664 (1989) ("The most recent legislation affecting the agricultural exemption was the 1974 Amendment at section $213(\mathrm{~g})$ which removed from the exemption any farm unit which is part of a conglomerate with annual gross sales of more than $\$ 10,000,000$, even if that unit would by itself have qualified for the exemption in terms of the man-day guidelines.").

269 Steven Pearlstein, For the Farm Lobby, Too Much Is Never Enough, WasH. Post (June 26, 2009), http://www.washingtonpost.com/wp-dyn/content/article/2009/06/25/ AR2009062504133.html.

270 S. REP. NO. 93-690, at 1506-07 (1974) ("Under the Committee bill between 90 and 95 percent of all the Nation's farms will remain uncovered by the Act. The only farms covered will continue to be the relatively large users of agricultural labor. The small family farm will continue to be exempt from coverage under the Act."). 
Broadcasting Act of 1961 ("SBA")271 can claim exempt status under Section 213(a)(3). The SBA provides professional sports teams with a limited antitrust exemption allowing them to pool the sale of their league's broadcast license rights to over-the-air networks like NBC, ABC, CBS, and Fox (i.e., so-called "sponsored telecasting"). 272 Each of the four major U.S. professional sports leagues relies on the protection afforded by the SBA to sign lucrative national television broadcast agreements with the over-the-air networks. ${ }^{273}$ The NFL, for example, earns approximately $\$ 3$ billion per year from such contracts. ${ }^{274}$ Consequently, by conditioning the leagues' continued antitrust immunity on their compliance with the FLSA, Congress could help ensure that teams in the four major professional sports leagues will pay all of their employees - game-day and non-game-day alike - in accordance with the minimum wage and overtime laws. ${ }^{275}$

271 15 U.S.C. \$\$ 1291-95 (2012).

27215 U.S.C. § 1291 ("The antitrust laws . . shall not apply to any joint agreement by or among persons engaging in or conducting the organized professional team sports of football, baseball, basketball, or hockey, by which any league of clubs participating in professional football, baseball, basketball, or hockey contests sells or otherwise transfers all or any part of the rights of such league's member clubs in the sponsored telecasting of the games of football, baseball, basketball, or hockey ...."); see also Grow, supra note 253, at 620 (discussing SBA).

The SBA was originally passed after the NFL saw its initial attempts to enter a league-wide television broadcasting agreement with the CBS television network enjoined by a federal district court as an illicit restraint of trade. United States v. Nat'l Football League, 196 F. Supp. 445, 447 (E.D. Pa. 1961) (issuing injunction). See also Stephen F. Ross, Monopoly Sports Leagues, 73 MinN. L. REv. 643, 659 (1989) (recounting the history of the SBA).

273 See Bob Condor, NHL, NBC Sign Record-Setting 10-Year TV Deal, NHL.COM (Apr. 19, 2011), http://www.nhl.com/ice/news.htm?id=560238 (reporting that the NHL receives $\$ 200$ million per year from its television contract with NBC); Paul J. Gough, NBA's \$7.4 Billion TV Deals Boosted by New Media, ReuTERs (June 28, 2007), http:// www.reuters.com/article/2007/06/28/us-nba-idUSN2830146220070628 (discussing the NBA's current television contracts); Mark Newman, MLB Reaches Eight-Year Agreement with FOX, Turner, MLB.com (Oct. 2, 2012), http://m.mlb.com/news/article/39362362 (stating that MLB will receive a total of $\$ 12.4$ billion over eight years from its most recent television contract).

274 See Mark Maske, NFL Completes TV Deal with Fox, CBS and NBC Totaling About $\$ 3$ Billion Per Year, WASH. POST (Dec. 14, 2011), http://www.washingtonpost.com/ sports/redskins/nfl-completes-tv-deal-with-fox-cbs-and-nbc-totaling-about-3-billionper-year/2011/12/14/gIQARJdmuO_story.html (discussing the NFL's current television agreements with Fox, CBS, and NBC).

275 The State of California has recently taken a different approach, enacting a law that will force California-based professional sports teams to provide their cheerleaders with all of the rights and benefits afforded under employment law. Assemb. B. 202, 2015-16 Gen. Assemb., Reg. Sess. (Cal. 2015) (signed into law July 15, 2015). While this new provision is a good start, it unfortunately does not offer any protection to 
These incremental steps would address some of the policy problems with Section 213(a)(3) by ensuring that seasonal amusement or recreation workers receive at least the minimum wage and that extremely profitable enterprises like professional sports franchises do not benefit from the exemption at all. However, even with these reforms, the exemption would remain in place for large numbers of low-revenue enterprises. Studies have shown that relatively smaller employers tend to be more likely to violate workers' employment rights than their larger counterparts ${ }^{276}$; even a capped Section 213(a)(3) would thus remove a basic set of economic protections from workers who need them the most. ${ }^{277}$ Moreover, as FLSA historian Marc Linder has argued, there is little economic justification for exempting small businesses from the FLSA's requirements, for:

[e]ven if the boosterist claim that small firms are a job growth machine were valid, the mere creation of jobs in firms that on average offer lower wages, fewer and inferior nonwage financial benefits, worse working conditions, fewer opportunities for acquiring greater skills, and less job security

other employees of professional sports teams that may also receive sub-minimum wages and/or be denied overtime benefits.

Another possible approach would be for municipalities to extract a contractual promise from sports teams to pay at least the minimum wage and overtime, and perhaps even a living wage indexed to the area cost of living, not only to construction workers engaged to build a taxpayer-funded stadium, but also to the team's game-day employees such as ticket takers, ushers, concessionaires, and parking attendants.

276 AnNette Bernhardt et al., Broken LaWs, UnProtected Workers: Violations OF EMPLOYMENT AND LABOR LAWS IN AMERICA'S CITIES 39 (2009), available at http://www.nelp.org/page/-/brokenlaws/BrokenLawsReport2009.pdf?nocdn=1 (finding in study of approximately 4,300 low-wage, front-line workers that "workers employed by companies with less than 100 employees were at greater risk of experiencing violations [of their labor and employment rights] than those employed by larger companies"); DAVID WeIL, ImProving WorkPlace Conditions Through STRATEGiC ENFORCEMENT: A RePORT to THE WAGE AND Hour Division 75 (2010), available at http://www.dol.gov/whd/resources/strategicEnforcement.pdf (noting that "smaller employers ... often face more competitive conditions in their local markets," leading to "violations of labor standards" for low-wage workers); see also Taken for a Ride, supra note 18 (detailing FLSA violations and other employment rights abuses experienced by immigrant fair and carnival workers).

277 See, e.g., Marc Linder, The Small-Business Exemption Under the Fair Labor Standards Act: The "Original" Accumulation of Capital and the Inversion of Industrial Policy, 6 J.L. \& POL'y 403, 494 (1998) ("Promoting small construction businesses by exempting them from labor standards laws not only deprives workers of the protections of those mandates, but also subjects them to other substandard conditions that are, to be sure, not unlawful, but are manifestly consequences of this sector's small and stagnant character."). 
is no reason to require their employees to subsidize them to the detriment of larger firms. ${ }^{278}$

A more sweeping set of FLSA reforms, then, would eliminate all exemptions, or at least revisit the statute's haphazard suite of exemptions in an attempt to create some uniformity and policy rationale for carving out certain industries or occupations. An overhaul of the FLSA's exemptions would, at minimum, root out exemptions that were motivated by racism (e.g. the farm and domestic worker exemptions);279 reexamine exemptions that benefit single, narrow interest groups (e.g. the exemptions for shellfish workers and wreath makers);280 and fix those exemptions that are unworkable from an administrability perspective (e.g., the "white collar" exemptions, which draw unclear lines between those managerial and professional employees who are exempt from, and those who are eligible for, overtime). ${ }^{281}$ If any exemptions are to remain in the statute, barring a persuasive policy rationale to the contrary, they should relieve employers only of the FLSA's overtime requirement and leave in place the minimum wage guarantee, which, at a mere $\$ 7.25$ per hour, is already lower than the living wage for many U.S. families. ${ }^{282}$ Further, as part of its overhaul of the FLSA, Congress should consider capping any exemptions that remain in the statute based on the employer's revenue in the manner discussed above, to ensure that the country's wealthiest employers are not profiting on the backs of workers who are paid sub-minimum wages.

\section{CONCLUSION}

This article has examined Section 213(a)(3), an often overlooked FLSA provision that exempts seasonal amusement or recreational establishments from the statute's minimum wage and overtime requirements. The article has reviewed the existing case law - much of it conflicting - that has applied the exemption, and proposed a new, simplified framework for determining its applicability. The article then applied this new framework to a series of recent FLSA lawsuits brought against professional sports teams, employers that

278 Id. at 493-94.

279 See supra note 31 and accompanying text.

280 See supra notes 32-34 and accompanying text.

281 See supra note 26 and accompanying text.

282 Amy K. Glasmeier, Update on 3/24/2014, Living Wage Calculator, MIT (Mar. 24, 2014), http://livingwage.mit.edu/articles/1-update-on-3-24-2014 ("The minimum wage does not provide a living wage for most American families."). 
may in some cases qualify for the Section 213(a)(3) exemption. Having determined that sports teams are, in many circumstances, exempt from the FLSA, the article concluded by considering the policy implications of the exemption and proposing various reforms to ensure that the FLSA can deliver on its promise of providing all workers "a fair day's pay for a fair day's work."283

283 Phillips v. Walling, 324 U.S. 490, 493 (1945). 